\title{
L-Amino Acid Oxidases From Mushrooms Show Antibacterial Activity Against the Phytopathogen Ralstonia solanacearum
}

\author{
Jerica Sabotič ${ }^{* t}$, Jože Brzin ${ }^{1}$, Jana Erjavec², Tanja Dreo², Magda Tušek Žnidarič², \\ Maja Ravnikar ${ }^{2}$ and Janko Kos ${ }^{1,3}$
}

${ }^{1}$ Department of Biotechnology, Jožef Stefan Institute, Ljubljana, Slovenia, ${ }^{2}$ Department of Biotechnology and Systems Biology, National Institute of Biology, Ljubljana, Slovenia, ${ }^{3}$ Faculty of Pharmacy, University of Ljubljana, Ljubljana, Slovenia

OPEN ACCESS

Edited by:

Marc Valls,

University of Barcelona, Spain

Reviewed by:

Anabela Portela Borges,

University of Porto, Portugal

Yasufumi Hikichi,

Köchi University, Japan

*Correspondence: Jerica Sabotic

Jerica.Sabotic@ijs.si

tORCID:

Jerica Sabotic

orcid.org/0000-0002-2404-0192

Specialty section:

This article was submitted to Plant Microbe Interactions,

a section of the journal

Frontiers in Microbiology

Received: 16 December 2019

Accepted: 23 April 2020

Published: 19 May 2020

Citation:

Sabotič J, Brzin J, Erjavec J,

Dreo T, Tušek Žnidarič M, Ravnikar M and Kos J (2020) L-Amino Acid

Oxidases From Mushrooms Show Antibacterial Activity Against the Phytopathogen Ralstonia solanacearum

Front. Microbiol. 11:977. doi: 10.3389/fmicb.2020.00977
Ralstonia solanaceraum is the quarantine plant pathogenic bacterium that causes bacterial wilt in over 200 host plants, which include economically important crops such as potato, tomato, tobacco, banana, and ginger. Alternative biological methods of disease control that can be used in integrated pest management are extensively studied. In search of new proteins with antibacterial activity against $R$. solanacearum, we identified L-amino acid oxidases (LAOs) from fruiting bodies of Amanita phalloides (ApLAO) and Infundibulicybe geotropa (CgLAO). We describe an optimized isolation procedure for their biochemical characterization, and show that they are dimeric proteins with estimated monomer molecular masses of 72 and $66 \mathrm{kDa}$, respectively, with isoelectric point of $\mathrm{pH}$ 6.5. They have broad substrate specificities for hydrophobic and charged amino acids, with highest $\mathrm{K}_{\mathrm{m}}$ for L-Leu, and broad $\mathrm{pH}$ optima at $\mathrm{pH} 5$ and $\mathrm{pH}$ 6, respectively. An enzyme with similar properties is also characterized from the mycelia of I. geotropa (CgmycLAO). Fractionated aqueous extracts of 15 species of mushrooms show that LAO activity against L-Leu correlates with antibacterial activity. We confirm that the $L A O$ activities mediate the antibacterial actions of $A p\llcorner A O, C g\llcorner A O$, and CgmycLAO. Their antibacterial activities are greater against Gram-negative versus Gram-positive bacteria, with inhibition of growth rate, prolongation of lag-phase, and decreased endpoint biomass. In Gram-positive bacteria, they mainly prolong the lag phase. These in vitro antibacterial activities of CgLAO and CgmycLAO are confirmed in vivo in tomato plants, while ApLAO has no effect on disease progression in planta. Transmission electron microscopy shows morphological changes of $R$. solanacearum upon LAO treatments. Finally, broad specificity of the antibacterial activities of these purified LAOs were seen for in vitro screening against 14 phytopathogenic bacteria. Therefore, these fungal LAOs show great potential as new biological phytoprotective agents and show the fruiting bodies of higher fungi to be a valuable source of antimicrobials with unique features.

\footnotetext{
Keywords: bacterial wilt, antimicrobial, Amanita phalloides, Clitocybe geotropa, oxidative stress, L-amino acid oxidase, antibacterial, phytophatogen

Abbreviations: ApLAO, Amanita phalloides L-amino acid oxidase; AUDPC, area under the disease progress curve; CgLAO, Infundibulicybe (previously Clitocybe) geotropa L-amino acid oxidase; CgmycLAO, mycelium-derived Infundibulicybe (previously Clitocybe) geotropa L-amino acid oxidase; CSM, complete supplement mixture; HcLAO, Hebeloma cylindrosporium L-amino acid oxidase; LAO, L-amino acid oxidase; PBS, phosphate-buffered saline; PHA, polyhydroxyalkanoate; YPG, yeast peptone glucose.
} 


\section{INTRODUCTION}

The search for new antibacterial agents is especially important against plant pathogenic bacteria where there are no effective chemical or biological agents available for plant protection (Payne et al., 2007; Sahu et al., 2017). One such plant pathogen is the quarantine bacterium Ralstonia solanacearum (Smith, 1896) Yabuuchi et al., 1996, which is the active agent for bacterial wilt in the plant family Solanaceae. $R$. solanacearum is a species complex that can infect over 200 host plants, which include economically important crops such as potato, tomato, eggplant, tobacco, banana, pelargonium, and ginger (Allen et al., 2005). Overall, $R$. solanacearum results in approximately US\$950 million annual losses worldwide. The most affected countries are China, Bangladesh, Uganda and Bolivia, which suffer between 30 and $90 \%$ annual crop losses, which can rise to $98 \%$ during crop storage (Allen et al., 2005; Yuliar et al., 2015).

L-amino acid oxidases (LAOs; E.C. 1.4.3.2) are enzymes that catalyze the oxidative deamination of L-amino acids to their corresponding $\alpha$-keto acids, with the generation of ammonia and hydrogen peroxide. They are flavoenzymes, and they show high stereospecificity toward L-isomers of amino acids (Lukasheva et al., 2011; Hossain et al., 2014). LAOs are widely distributed in nature, and they fulfill a wide spectrum of biological roles in nitrogen metabolism and in the protection against antagonists, with antimicrobial activities representing one of their main functions. Moreover, LAOs represent a major component of snake venoms, where they serve as toxins, which have been studied in great detail to date. These are flavin adenine dinucleotide or flavin mononucleotide binding proteins, with molecular masses from 50 to $300 \mathrm{kDa}$, and isoelectric points between $\mathrm{pH} 4.0$ and 9.4. They are usually glycosylated and form non-covalently associated homodimers. Most LAOs have a broad range of substrate specificities, with preference for hydrophobic amino-acid substrates, including L-Phe, L-Leu, L-Trp, L-Met, and L-Ile. On the other hand, some LAOs have very narrow substrate specificities, with high preference for basic L-amino acids, such as L-Lys oxidase from Trichoderma viride. The biological effects of LAOs are mediated through their enzymatic activity in two ways: (i) via elimination of amino acids from the extracellular environment, which can cause nutrient deficiency, and/or (ii) via binding to the surface of cells and generating high local concentrations of hydrogen peroxide, which can lead to cell death (Du and Clemetson, 2002; Lukasheva et al., 2011; Guo et al., 2012; Hossain et al., 2014). Several snake venom LAOs have strong antibacterial activities that show wide variations in their selectivities and specificities against Gram-positive and/or Gramnegative bacteria (Guo et al., 2012; Izidoro et al., 2014). Only a few LAOs have been isolated from fungi, however, a recent screening of LAO activities in fungal fruiting bodies revealed that they represent a new rich and readily accessible source of versatile and robust enzymes with LAO activities (Žun et al., 2017).

Although there have been extensive studies on biological control of R. solanaceraum (Anith et al., 2004; Ji et al., 2005; Messiha et al., 2007; Hong et al., 2011; Maji and Chakrabartty, 2014; Yuliar et al., 2015), to date there are no efficient chemical or biological agents available for its control. So far, only a few fungal proteins have been tested in the field of agricultural crop protection, including tamavidin (Takakura et al., 2012), mycocypins (Šmid et al., 2013, 2015) and different lectins (Pohleven et al., 2011; Sabotič et al., 2016). The only example of mushroom proteins that are active against bacterial plant pathogens was reported by Zheng et al. (2010), who isolated an antibacterial protein from dried fruiting bodies of the mushroom Clitocybe sinopica, however, they did not perform any in vivo tests (Zheng et al., 2010). A screening study for antibacterial activities against $R$. solanacearum that included 150 aqueous extracts of fungal fruiting bodies from 94 different species revealed complete growth inhibition of $R$. solanacearum in vitro for 11 of these extracts. Two extracts were selected for isolation and characterization of the antibacterial active substance. One was from the poisonous death cap Amanita phalloides (Fries) Link (1833), which showed broad antibacterial activity in vitro against Gram-negative bacteria but no in vivo activity. The other was from the edible trooping funnel mushroom Infundibulicybe geotropa (Buillard ex DeCandolle) Harmaja (2003), which showed antibacterial activity against different strains of Ralstonia spp., and also antibacterial activity in vivo for both tomato and potato (Erjavec et al., 2016).

Here, we describe the biochemical characterization of proteins with antibacterial activity against $R$. solanacearum that are isolated from fruiting bodies of A. phalloides and I. geotropa, and from I. geotropa cultured mycelia. I. geotropa has been reclassified taxonomically from Clitocybe geotropa, however, the abbreviation of the protein name $(\mathrm{CgLAO})$ as well as that from the mycelium (CgmycLAO) is maintained here for continuity of the characterization of these proteins, as their apoptosis-inducing activities on cancer cell lines were published previously (Pišlar et al., 2016). We determined the antibacterial activities of these isolated proteins against $R$. solanacearum both in vitro and in vivo. We finally indicate a possible mechanism of action for the I. geotropa protein through electron microscopy analysis of $R$. solanacearum cells in the presence of the purified protein fraction from I. geotropa, and through determining the effects of these isolated antibacterial proteins on model Gram-positive and Gramnegative bacteria.

\section{MATERIALS AND METHODS}

\section{Materials and Fungal Samples}

The L-amino acids L-Thr, L-Gly, L-Ala, L-Met, L-Phe, and L-Tyr were from Serva (Heidelberg, Germany), L-Arg, L-Val, and L-Trp from Fluka (Buchs, Switzerland), L-Pro from Merck (Darmstadt, Germany) and L-His, L-Lys, L-Asp, L-Glu, L-Ser, L-Asn, L-Gln, L-Cys, L-Ile, and L-Leu from Sigma-Aldrich (St. Louis, MO, United States). Complete supplement mixture (CSM) was from Formedium (Norfolk, United Kingdom), and peptide N-glycosidase F was from Roche Diagnostics (Basel, Switzerland). Horseradish peroxidase, catalase and other reagents (all of analytical or sequencing grade) were from SigmaAldrich (St. Louis, MO, United States). Glutaraldehyde, osmium 
tetroxide, and uranyl acetate were from SPI Supplies (West Chester, PA, United States), Paraformaldehyde, epoxy resins agar 100 and lead citrate were from Agar Scientific (Essex, United Kingdom). Yeast extract and casamino acids were from Difco (Detroit, MI, United States), proteose peptone, bactopeptone and agar from Oxoid (Basingstoke, United Kingdom), glucose and sucrose from Kemika (Zagreb, Croatia), malt extract from BioMerieux (Marcy l'Etoile, France), and M17 from Merck (Darmstadt, Germany). Fruiting bodies of Agaricus bisporus (J. E. Lange) Imbach 1946, Macrolepiota procera (Scop.) Singer 1948, Coprinopsis cinerea (Schaeff.) Redhead, Vilgalys and Moncalvo 2001, Amanita phalloides (Vaill. ex Fr.) Link 1833, Amanita rubescens Pers. 1797, Hygrophorus erubescens (Fr.) Fr. (1838), Hygrophorus russula (Schaeff. ex Fr.) Kauffman (1918), Infundibulicybe geotropa (Bull.) Harmaja (2003), Clitocybe nebularis (Batsch) P. Kumm. (1871), Lepista nuda (Bull.) Cooke (1871), Tricholoma saponaceum (Fr.) P. Kumm. (1871), Imleria badia (Fr.) Vizzini (2014), Suillus variegatus (Sw.) Richon and Roze (1888), Cantharellus cibarius Fr. (1821), and Tuber mesentericum Vittad. (1831) (Table 1) were collected in their natural habitat in forest stands or grasslands in central and western Slovenia and frozen at $-20^{\circ} \mathrm{C}$. The taxonomic classification follows the Index Fungorum database ${ }^{1}$.

\section{Isolation of I. geotropa LAO From Fruiting Bodies and Vegetative Mycelia}

After thawing, $240 \mathrm{~mL}$ of crude aqueous extract was pressed out of $500 \mathrm{~g}$ of the fruiting bodies. After addition of $2 \mathrm{M} \mathrm{NaSCN}$ and $3 \mathrm{M}$ urea, the extract was concentrated by ultrafiltration

${ }^{1}$ http://www.indexfungorum.org using 3-kDa cut-off membranes. The precipitated material was removed by centrifugation at $8000 \times g$ for $20 \mathrm{~min}$ at $4^{\circ} \mathrm{C}$. The samples were then divided into three equal portions, with each applied to a preparative gel filtration chromatography column $(4 \times 110 \mathrm{~cm}$; flow rate, $42 \mathrm{~mL} / \mathrm{h}$; fraction volume, $17 \mathrm{~mL}$ ) using Sephacryl S200 (GE Healthcare Life Sciences, Uppsala, Sweden) equilibrated in $0.02 \mathrm{M}$ Tris- $\mathrm{HCl}, \mathrm{pH} \mathrm{7.5,}$ with $0.3 \mathrm{M} \mathrm{NaCl}$ and $3 \mathrm{M}$ urea (buffer A). The fractions with antibacterial activity were pooled, concentrated by ultrafiltration, and dialyzed against $50 \mathrm{mM}$ phosphate buffer, $\mathrm{pH} 6.8$ (buffer B), which contained $0.85 \mathrm{M}$ ammonium sulfate. They were then applied to a hydrophobic interaction chromatography column $(3 \times 35 \mathrm{~cm}$; flow rate, $19.2 \mathrm{~mL} / \mathrm{h}$; fraction volume, $12 \mathrm{~mL})$ using phenyl-Sepharose (GE Healthcare Life Sciences, Uppsala, Sweden) equilibrated in buffer B. The bound protein was eluted using a linear gradient of ammonium sulfate, from 0.85 to $0 \mathrm{M}$ in buffer $\mathrm{B}(1200 \mathrm{~mL})$, followed by a gradient of 0 to $20 \%$ ethanol in buffer B $(400 \mathrm{~mL})$. The fractions with the highest antibacterial activities were pooled and concentrated by ultrafiltration. This is an optimized protocol from the previously published CgLAO purification (Pišlar et al., 2016) with highly improved yield.

Infundibulicybe geotropa mycelia were cultivated as described previously (Erjavec et al., 2016), collected by filtration through cheesecloth, and centrifuged $\left(8000 \times g\right.$ for $10 \mathrm{~min}$ at $\left.4^{\circ} \mathrm{C}\right)$ and stored at $-20^{\circ} \mathrm{C}$ until use. The solid mycelia (15 g) were homogenized in liquid nitrogen, and the protein from this hyphal powder was extracted overnight in $100 \mathrm{~mL}$ buffer $\mathrm{A}$. The insoluble material was removed by centrifugation $(16000 \times g$ for $5 \mathrm{~min}$ at $4^{\circ} \mathrm{C}$ ), and the resulting crude I. geotropa mycelium extract was subjected to the same purification procedure as the crude fruiting body extracts.

TABLE 1 | Antibacterial activities against $R$. solanacearum and LAO activities (at $\mathrm{pH} 5.5$ ) in the fungal fruiting body extracts and their gel filtration fractions.

\begin{tabular}{|c|c|c|c|c|c|c|c|}
\hline \multirow[t]{2}{*}{ Family } & \multirow[t]{2}{*}{ Species } & \multirow{2}{*}{$\begin{array}{l}\text { Estimated Mw of } \\
\text { active fraction } \\
\text { (kDa) }\end{array}$} & \multicolumn{2}{|c|}{ In vitro antibacterial activity } & \multicolumn{3}{|c|}{ LAO activity of gel filtration fractions } \\
\hline & & & Extract & $\begin{array}{l}\text { Active } \\
\text { fraction }\end{array}$ & $\begin{array}{l}\text { In-gel } \\
\text { vs. amino acids in CSM }\end{array}$ & \multicolumn{2}{|l|}{ In-solution } \\
\hline \multirow[t]{2}{*}{ Agaricaceae } & Agaricus bisporus & 25 & - & - & + & + & - \\
\hline & Macrolepiota procera & na & - & - & - & - & - \\
\hline & Amanita rubescens & na & nd & - & - & - & - \\
\hline \multirow[t]{2}{*}{ Hygrophoraceae } & Hygrophorus erubescens & na & - & - & - & - & - \\
\hline & Hygrophorus russula & na & - & - & - & - & - \\
\hline \multirow[t]{2}{*}{ Tricholomataceae } & Infundibulicybe geotropa & 80 & + & + & + & + & + \\
\hline & Clitocybe nebularis & 30 & + & \pm & + & + & - \\
\hline Hydnaceae & Cantharellus cibarius & na & nd & - & - & - & - \\
\hline Tuberaceae & Tuber mesentericum & 50 & - & + & + & + & + \\
\hline
\end{tabular}

Details of the elution profiles for the LAO and antibacterial activities of the gel filtration fractions are illustrated in Supplementary Figure S4. \pm , Antibacterial activity detected in a different fraction than LAO activity. na, not applicable (no activity); nd, not determined. CSM, complete supplement mixture. 


\section{Isolation of $A$. phalloides LAO From Fruiting Bodies}

The isolation procedure for A. phalloides LAO (ApLAO) was the same as that used for I. geotropa LAO $(C g L A O)$, except that $2 \mathrm{M} \mathrm{NaSCN}$ was omitted in the extract preparation. The two separation steps using gel filtration and hydrophobic interaction chromatography were as described above for $\mathrm{CgLAO}$.

\section{SDS-PAGE, Two-Dimensional SDS-PAGE, Native PAGE, and Isoelectric Focusing}

The proteins were routinely analyzed on $10 \%$ polyacrylamide gels under denaturing and reducing conditions, and visualized using Coomassie brilliant blue staining or silver staining. Non-denaturing and non-reducing conditions were used for analyses of protein complexes and LAO activities. Low molecular weight markers of 14.4 to $97 \mathrm{kDa}$ (GE Healthcare, Chicago, IL, United States) were used for molecular mass estimations.

For the two-dimensional SDS-PAGE analysis, the protein was precipitated by trichloroacetic acid/acetone, vacuum dried, and reconstituted in $125 \mu \mathrm{L}$ rehydration buffer (7 M urea, $2 \mathrm{M}$ thiourea, $30 \mathrm{mM}$ Tris, $0.25 \%$ amidosulphobetaine-14, $2.5 \%$ 3-[(3-cholamidopropyl)dimethylammonio]-1-propanesulfonate (CHAPS), $0.002 \%$ bromophenol blue, $1 \%$ ampholytes, $12 \mu \mathrm{L} / \mathrm{mL}$ destreak reagent). A Ettan IPGphor II isoelectric focusing (IEF) system (GE Healthcare, Chicago, IL, United States) was used, and $7 \mathrm{~cm}$ Immobiline DryStrip pH gradient (IPG) strips 3-11 NL (GE Healthcare, Chicago, IL, United States) were passively rehydrated overnight with the protein samples. The IEF was performed at $20^{\circ} \mathrm{C}$ using the following sequential steps: $300 \mathrm{~V}$ for $45 \mathrm{~min} ; 300 \mathrm{~V}$ to $1000 \mathrm{~V}$ linear gradient for $30 \mathrm{~min}$; $1000 \mathrm{~V}$ to $5000 \mathrm{~V}$ linear gradient for $72 \mathrm{~min}$; and $5000 \mathrm{~V}$ to the final $6000 \mathrm{Vh}$. The current was restricted to $50 \mu \mathrm{A} / \mathrm{strip}$. The focused IPG strips were exposed to $65 \mathrm{mM}$ dithiothreitol followed by $135 \mathrm{mM}$ iodoacetamide in $75 \mathrm{mM}$ Tris- $\mathrm{HCl}$ buffer with $6 \mathrm{M}$ urea, $4 \%$ sodium dodecyl sulfate, $30 \%$ glycerol and $0.002 \%$ bromophenol blue. Then, $10 \%$ polyacrylamide gels were used for the second dimension of the SDS-PAGE, which were stained by the highly sensitive imidazole-zinc negative staining, as described previously (Fernandez-Patron et al., 1992). The protein spots were excised and stored at $-20^{\circ} \mathrm{C}$ before further processing.

The proteins were analyzed under non-denaturing conditions using blue native PAGE with a Novex NativePAGE BisTris gel system with 4 to $16 \%$ gradient protein gels (Life Technologies, Carlsbad, CA, United States), according to the manufacturer instructions. NativeMark unstained protein standards (ThermoFisher Scientific, Waltham MA, United States) was used for the molecular mass estimations.

Isoelectric focusing was carried out with a Pharmacia PhastSystem, using commercial precast $\mathrm{pH}$ 3-9 gradient gels (GE Healthcare, Chicago, IL, United States) following the manufacturer instructions. Alternatively, precast Novex $\mathrm{pH}$ 3-7 IEF protein gels (Life Technologies, Carlsbad, CA, United States) were used. Marker proteins with pI values from 3.5 to 9.3 were used for calibration (GE Healthcare, Chicago, IL, United States).

\section{Protein Glycosylation Analysis}

The glycosylation of proteins was assessed using treatment with peptide N-glycosidase (Magnelli et al., 2011). Protein samples were denatured by heating to $100^{\circ} \mathrm{C}$ for $10 \mathrm{~min}$ in $1 \%$ sodium dodecyl sulfate, and were then mixed with $50 \mathrm{mM} \mathrm{Na} \mathrm{HPO}_{4}$, pH 7.5, with 1.5\% CHAPS before peptide N-glycosidase F (3 U) was added to half of each sample; the other half of each sample served as the controls. Both of these samples were incubated at $37^{\circ} \mathrm{C}$ for $24 \mathrm{~h}$, and then subjected to SDS-PAGE analysis under reducing conditions.

\section{Mass Spectrometry and N-Terminal Sequence Analysis}

The proteins were resolved in one- or two-dimensional SDSPAGE, and the individual bands and spots were excised. After in-gel trypsin digestion, they were identified by peptide mass fingerprinting (Ganten et al., 2006) using an ion trap mass spectrometer (1200 series HPLC-Chip-LC/MSD Trap XCT Ultra; Agilent Technologies, Santa Clara, CA, United States). Database searches were performed using the Mascot in-house server for the MS/MS ion searches.

The N-terminal amino-acid sequences of the proteins were determined by automated amino-acid sequencing using Procise Protein Sequencing System 492 (Applied Biosystems, Foster City, CA, United States). The proteins were resolved by SDS-PAGE, electroblotted onto polyvinylidene difluoride membranes, and stained with Coomassie blue. The individual protein bands were then excised and analyzed (Reim and Speicher, 2001).

\section{LAO Activity Assay}

The LAO activities of the protein samples were determined spectrophotometrically, as described previously (Kishimoto and Takahashi, 2001). Briefly, each protein sample was mixed with the reaction mixture that contained the substrate $(5 \mathrm{mM} \mathrm{L}$-amino acid or amino acids in $0.1 \%$ CSM), $2 \mathrm{mM}$ o-phenylenediamine and $0.81 \mathrm{U} / \mathrm{mL}$ horseradish peroxidase in $0.1 \mathrm{M}$ bis-Tris, $\mathrm{pH} 5.5$, in 96-well microplates. Absorbance at $420 \mathrm{~nm}$ was measured at constant time intervals over $30 \mathrm{~min}$ at $30^{\circ} \mathrm{C}$ in a microplate reader (Infinite M1000; Tecan, Grödig, Austria). For substrate specificity analysis, the individual L-amino acids $(5 \mathrm{mM})$ were used in the reaction mixture. For inhibition of LAO activity, ascorbic acid was added to the reaction mixture to final concentrations of 0.1 to $5 \mathrm{mg} / \mathrm{mL}$.

For the optimum $\mathrm{pH}$ analysis for the LAO activities, these were analyzed as described above with L-Leu as the substrate and in phosphate-citrate buffer from $\mathrm{pH} 2.6$ to $\mathrm{pH} 7.8$, K-phosphate buffer from $\mathrm{pH} 6$ to $\mathrm{pH} 9$, and carbonate-bicarbonate buffer from $\mathrm{pH} 9$ to $\mathrm{pH} 11$.

In-gel analysis of the LAO activities was performed as described previously (Žun et al., 2017). Briefly, non-denatured samples were subjected to SDS-PAGE in $10 \%$ polyacrylamide gels. After electrophoresis, the gels were washed in $0.1 \mathrm{M}$ bis-Tris, $\mathrm{pH}$ 5.5, and then incubated in the reaction mixture containing substrate $(5 \mathrm{mM} \mathrm{L}$-amino acid or amino acids in $0.1 \%$ CSM), $1 \mathrm{mM}$ o-phenylenediamine and $0.5 \mathrm{U} / \mathrm{mL}$ horseradish peroxidase, in the same buffer at room temperature in the dark 
for 1 to $20 \mathrm{~h}$. After stopping the reaction by adding $2 \mathrm{M} \mathrm{H}_{2} \mathrm{SO}_{4}$, the brown bands of the LAO activity were analyzed using an image scanner (Canon LiDE 110, Middlesex, United Kingdom).

\section{Bacterial Cultures and Inoculum Preparation}

The National Collection of Plant Pathogenic Bacteria strain 4156 Ralstonia solanacearum (Smith, 1896) Yabuuchi et al., 1996 (phylotype IIB, race 3, biovar 2) (Wullings et al., 1998) was isolated from potatoes in 2001 in Netherlands. This was used as the study reference isolate for the in vitro testing of antibacterial activity. $R$. solanacearum were grown at $28^{\circ} \mathrm{C}$ on yeast peptone glucose (YPG) agar plates (per liter: $5 \mathrm{~g}$ yeast extract, $5 \mathrm{~g}$ proteose peptone, $10 \mathrm{~g}$ glucose, $12 \mathrm{~g}$ agar; $\mathrm{pH}$ 7.2-7.4). Bacterial suspensions were prepared in $0.01 \mathrm{M}$ phosphate-buffered saline (PBS) (per liter: $1.071 \mathrm{~g} \mathrm{Na}_{2} \mathrm{HPO}_{4}, 0.4 \mathrm{~g} \mathrm{NaH}_{2} \mathrm{PO}_{4} 7 \mathrm{H}_{2} \mathrm{O}, 8.0 \mathrm{~g}$ $\mathrm{NaCl} ; \mathrm{pH}$ 7.2). The bacterial concentrations were determined according to absorbance at $595 \mathrm{~nm}\left(\mathrm{~A}_{595}\right)$, and they were dilution plated on YPG agar $(\mathrm{CFU} / \mathrm{mL})$. Alternatively, BG medium (per liter: $10 \mathrm{~g}$ bacto-peptone, $1 \mathrm{~g}$ yeast extract, $1 \mathrm{~g}$ casamino acids, $5 \mathrm{~g}$ glucose) was used for $R$. solanacearum cultivation.

\section{In vitro Testing of Antibacterial Activity Against $\boldsymbol{R}$. solanacearum and Other Plant Pathogenic Bacteria}

The in vitro testing for antibacterial activities was performed in microtiter plates following a previously published protocol (Erjavec et al., 2016). Briefly, the $200 \mu \mathrm{L}$ testing wells contained YPG $(75 \mu \mathrm{L})$, the suspension of $R$. solanacearum $\left(10^{7}\right.$ cells $/ \mathrm{mL}$, $75 \mu \mathrm{L}), 0.01 \mathrm{M}$ PBS $(42.5 \mu \mathrm{L})$ and the mushroom extract or protein fraction $(7.5 \mu \mathrm{L})$. The following controls were included for each plate: positive control (no extract added) indicating the normal growth of $R$. solanacearum in these conditions; negative control (no extract and $R$. solanacearum added); and controls of extract sterility (no $R$. solanacearum added). All of the controls were supplemented to $200 \mu \mathrm{L}$ with $0.01 \mathrm{M}$ PBS. Each sample (i.e., mushroom extract) and the controls were tested in at least two parallel wells. After $24 \mathrm{~h}$, absorbance at $595 \mathrm{~nm}$ was measured and $30 \mu \mathrm{L}$ of the mixture from each well was plated onto fresh YPG agar plates, to determine whether the effects were bactericidal (i.e., no bacterial growth observed when transferred onto fresh medium) or bacteristatic (i.e., bacterial growth observed when transferred onto fresh medium). The effects of the fungal extracts on selected plant pathogenic bacteria [Dickeya spp. (NIB B16 and NIB S1), Dickeya fangzhongdai (DSMS 101947), Erwinia amylovora (NCPPB 683), Pseudomonas syringae pv. syringae (NCPPB 281), Clavibacter michiganensis subsp michiganensis (NCPPB 2979), Agrobacterium tumefaciens (NCPPB 2437), Enterobacter sp. (NCCPB 4168), Pectobacterium atrosepticum (NIB Z 620), Pectobacterium carotovorum (NIB Z 623), Dickeya chrysanthemi (NCPPB 402), Escherichia coli (GSPB 48), Ralstonia mannitolilytica (CFBP 6737), and Xanthomonas arboricola pv. pruni (NCPPB 416)] were tested in media that support good bacterial growth, which included casamino acidpeptone-glucose (CPG) medium (per liter: $1 \mathrm{~g}$ casamino acids, $10 \mathrm{~g}$ peptone, $5 \mathrm{~g}$ glucose), King's medium B (KB; per liter: $20 \mathrm{~g}$ proteose peptone, $1.5 \mathrm{~g} \mathrm{~K}_{2} \mathrm{HPO}_{4}, 1.5 \mathrm{~g} \mathrm{MgSO} 47 \mathrm{H}_{2} \mathrm{O}, 10 \mathrm{~mL}$ glycerol), nutrient broth yeast extract (NBYE; per liter: $8 \mathrm{~g}$ nutrient broth, $5 \mathrm{~g}$ yeast extract, $\mathrm{pH}$ 7.5) and YPG (Schaad et al., 2001). ApLAO, CgLAO and the LAO extracted from mycelia of I. geotropa (CgmycLAO) were tested for their effect on the growth of $R$. solanacearum using the highest concentration available for each sample at different concentrations, as indicated in Table 3.

The combined effects of the purified LAO enzymes and catalase $(1000 \mathrm{U} / \mathrm{mL})$ on $R$. solanacearum were tested in liquid YPG and BG media.

\section{In vitro Testing of Antibacterial Activities Against Escherichia coli and Lactococcus lactis}

The Gram-negative bacterium Escherichia coli DH5 $\alpha$ and the Gram-positive bacterium Lactococcus lactis NZ9000 were used to define the antimicrobial mechanism of the LAO activities. Growth curves were followed in rich media, S.O.C. ( $2 \%$ tryptone, $0.5 \%$ yeast extract, $10 \mathrm{mM} \mathrm{NaCl}, 2.5 \mathrm{mM}$ $\mathrm{KCl}, 10 \mathrm{mM} \mathrm{MgSO}$, $0.4 \%$ glucose) for E. coli, and GM17 (M17 from Merck supplemented with $0.5 \%$ glucose) for L. lactis. Overnight cultures were diluted 100-fold in the corresponding fresh medium, to which the filter sterilized LAO samples were added at different concentrations (ApLAO, 64-0.08 $\mu \mathrm{g} / \mathrm{mL}$; CgLAO, 99-1.6 $\mu \mathrm{g} / \mathrm{mL}$; CgmycLAO, 129$21 \mu \mathrm{g} / \mathrm{mL})$. Alternatively, E. coli growth was followed in M9 minimal medium $\left(0.24 \mathrm{M} \mathrm{Na}_{2} \mathrm{HPO}_{4}, 0.24 \mathrm{M} \mathrm{KH}_{2} \mathrm{PO}_{4}\right.$, $0.09 \mathrm{M} \mathrm{NaCl}, 0.19 \mathrm{M} \mathrm{NH} \mathrm{N}_{4} \mathrm{Cl}, 1 \mathrm{mM} \mathrm{MgSO}_{4}, 0.1 \mathrm{mM}$ $\mathrm{CaCl}_{2}, 2 \%$ glucose) without or with $5 \mathrm{mM} \mathrm{L-Leu.} \mathrm{The}$ effects of catalase addition were determined in the rich medium using bovine catalase at $1000 \mathrm{U} / \mathrm{mL}$. Growth curves (as triplicates) were followed at $30^{\circ} \mathrm{C}$ by measuring $\mathrm{A}_{595}$ in 96-well plates using a microplate reader (Sunrise; Tecan, Grödig, Austria) and the XFluor4 software, and analyzed using DMFit Microsoft Excel Add-In, version 3.5 (Baranyi and Roberts, 1994).

\section{Tomato Pathogenicity Test}

Tomato pathogenicity tests were used to determine the in vivo activities of the A. phalloides and I. geotropa extracts and the purified LAO enzymes. The same protocols were used as described by Erjavec et al. (2016). Briefly, tomato plants (Solanum lycopersicon cv. "Moneymaker") were used as the test plant. The plants were inoculated at the two-tothree true-leaf stage with mixtures of the $R$. solanacearum suspensions and mushroom extracts or protein samples (10:1 ratio). The bacterial concentration in the inoculation suspension was $10^{5} \mathrm{CFU} / \mathrm{mL}$, and the concentrations of the purified LAO enzymes were $2.14 \mathrm{mg} / \mathrm{mL}$ for $A p \mathrm{LAO}$, $3.3 \mathrm{mg} / \mathrm{mL}$ for $\mathrm{CgLAO}$, and $4.3 \mathrm{mg} / \mathrm{mL}$ for CgmycLAO. The $R$. solanacearum suspension and 0.01 M PBS were used for the inoculation of the positive and negative control plants, respectively. Using a sterile needle (Icogamma plus, $0.6 \mathrm{~mm} \times 25 \mathrm{~mm}$; Novico, Italy), each suspension was inoculated between the cotyledons, with approximately $20 \mu \mathrm{L}$ of each suspension used per plant. 
In total, 42 plants were inoculated with each extract, 42 plants with the positive controls, and 20 plants with the negative controls. After the inoculations, the plants were grown at a $28^{\circ} \mathrm{C}$ day temperature, with a $16 \mathrm{~h}$ photoperiod at $90 \mu \mathrm{mol}$ $\mathrm{m}^{-2} \mathrm{~s}^{-1}$ photon irradiance, and at a $20^{\circ} \mathrm{C}$ night temperature. The severities of the symptoms were evaluated regularly over 14 days, following the numerical grades of Winstead and Kelman (1952): 0 (no symptoms), 1 (one leaf wilted), 2 (2-3 leaves wilted), 3 (all leaves except the tip of the plant wilted), 4 (all leaves and the tip of the plant wilted), and 5 (plant dead).

Chi-squared tests were used for symptom severities and disease progression in plants inoculated with mixtures of $R$. solanacearum and protein samples, compared with the positive control plants. The area under the disease progress curve (AUDPC) was used as a measure of quantitative disease resistance, as calculated for the pathogenicity tests (Madden et al., 2007) using the R-statistical (R Development Core Team, 2008) Agricolae package (De mendiburu, 2020).

\section{Transmission Electron Microscopy}

The ultrastructure of the bacterial cells was examined using transmission electron microscopy. Overnight cultures were mixed with $\mathrm{CgLAO}(50 \mu \mathrm{g} / \mathrm{mL})$ for $2 \mathrm{~h}$ and compared with untreated cells. The cells were fixed in 3\% glutaraldehyde and $1 \%$ paraformaldehyde in $0.1 \mathrm{M}$ phosphate buffer, post-fixed in $2 \%$ osmium tetroxide, and embedded in epoxy resin. Ultrathin sections were cut and examined under transmission electron microscopy (CM 100; Philips, Amsterdam, Netherlands), operating at $80 \mathrm{kV}$. Micrographs were recorded with a CCD camera (Orius SC 200; Gatan Inc., United States).

\section{RESULTS}

\section{Isolation of Antibacterial Substances From Crude Protein Extracts of Amanita phalloides and Infundibulicybe geotropa}

Proteins that showed antibacterial activities against $R$. solanacearum were isolated from the fruiting bodies of A. phalloides and I. geotropa using a two-step procedure of gel filtration (Figure 1) and hydrophobic-interaction chromatography (Figure 2). These yielded purified proteins of 72 and $66 \mathrm{kDa}$ from A. phalloides and I. geotropa, respectively, as shown by SDS-PAGE analysis (Figure 3). For the preparation of the crude protein extract from $A$. phalloides, little benefit was seen for the inclusion of $\mathrm{NaSCN}$ with the $3 \mathrm{M}$ urea, and so this potential activation step of $\mathrm{NaSCN}$ was omitted from the protocol. On the other hand, for the preparation of the crude protein extract from I. geotropa fruiting bodies, the addition of $2 \mathrm{M} \mathrm{NaSCN}$ with the $3 \mathrm{M}$ urea resulted in an approximately 10-fold increase in the total LAO activity of the extract, so this step was included in the purification scheme.

In a typical preparation, 3.8 and $9.0 \mathrm{mg}$ of the antibacterial proteins were obtained from $500 \mathrm{~g}$ of A. phalloides and I. geotropa fruiting bodies, respectively.
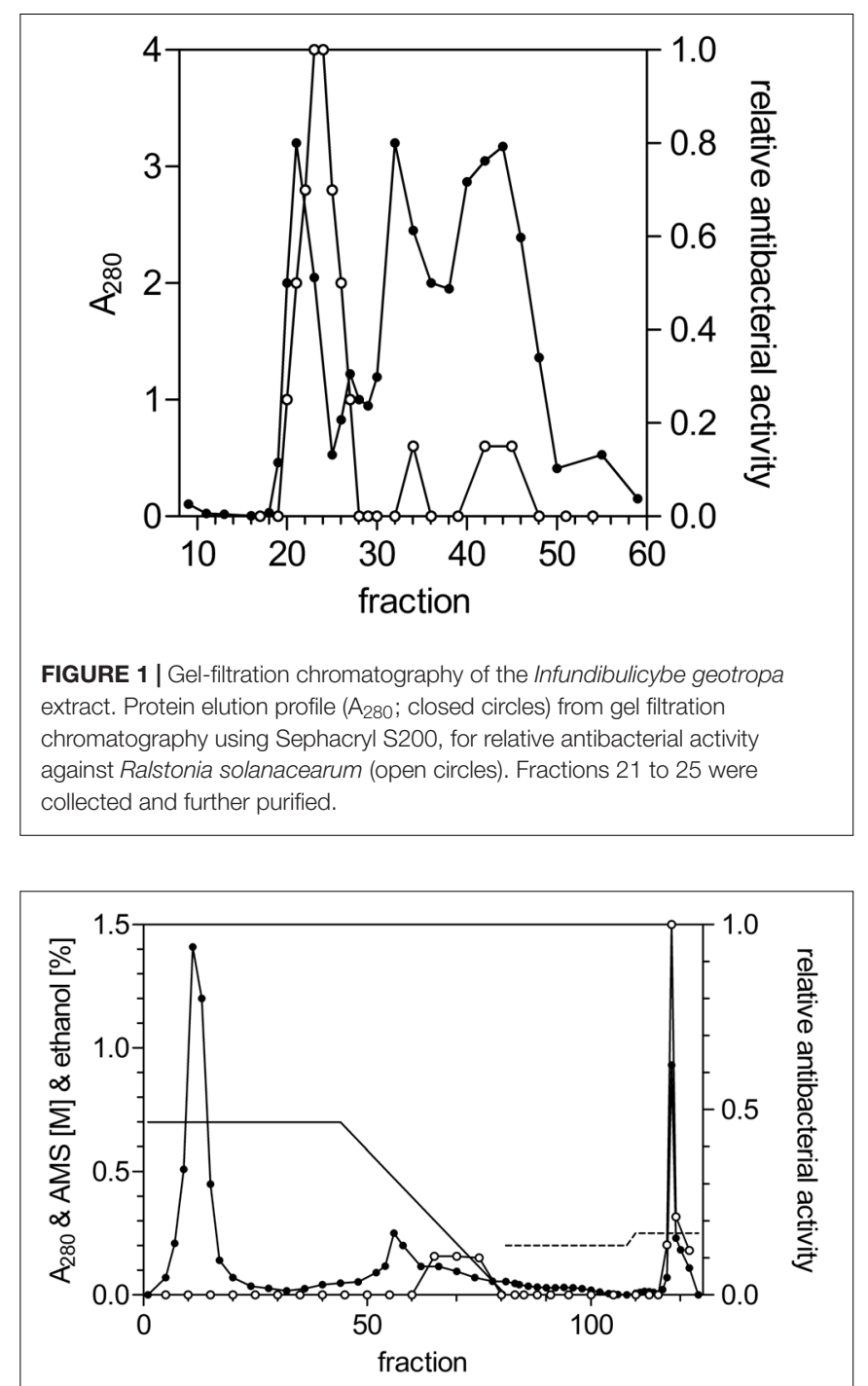

FIGURE 2 | Hydrophobic-interaction chromatography of the fractions with antibacterial activity against $R$. solanacearum from the gel filtration of the 1. geotropa extract. Protein elution profile $\left(A_{280}\right.$; closed circles) from hydrophobic interaction chromatography using Phenyl-Sepharose for relative antibacterial activity against $R$. solanacearum (open circles). Solid line, ammonium sulfate gradient; dotted line, ethanol concentration. Fractions 118-120 were collected and concentrated by ultrafiltration.

\section{The Proteins With Antibacterial Activity Are L-Amino Acid Oxidases}

Under native conditions, the molecular masses of the purified antibacterial proteins from A. phalloides and I. geotropa were estimated to be in the 120 to $130 \mathrm{kDa}$ range from the elution volumes on a calibrated gel filtration column (data not shown), which suggested that both proteins form dimers. Furthermore, apparent molecular masses in the 180 to $300 \mathrm{kDa}$ range were obtained using native PAGE analysis (Figure 4B). The antibacterial protein purified from A. phalloides fruiting bodies ran at $220 \mathrm{kDa}$ as a diffuse band, whereas two bands of approximately 180 and $360 \mathrm{kDa}$ were observed for the 


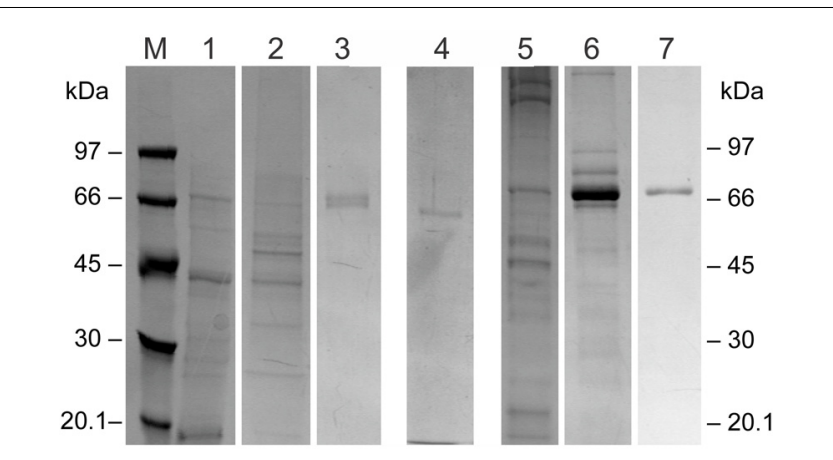

FIGURE 3 | Representative SDS-PAGE analysis of the fractions showing antibacterial activity after the two-step purification procedure of the 1. geotropa and A. phalloides extracts. SDS-PAGE in a $10 \%$ polyacrylamide gel under denaturing conditions visualized by Coomassie blue staining. Lane M, molecular mass markers; lane 1, crude aqueous extract of I. geotropa fruiting bodies; lane 2, gel filtration fractions 21-25 of CgLAO; lane 3, fraction 118 after hydrophobic-interaction chromatography of $C g\llcorner A O$; lane 4, purified CgmycLAO; lane 5, crude aqueous extract of $A$. phalloides fruiting bodies; lane 6, gel filtration fractions 23-32 of ApLAO; lane 7, fractions 113-117 after hydrophobic-interaction chromatography of $A p L A O$.

antibacterial protein purified from I. geotropa fruiting bodies. The bands were excised from native PAGE, with the proteins eluted overnight by diffusion from gel pieces and the antibacterial activities against Ralstonia solanacearum were confirmed in vitro. The molecular masses revealed by PAGE analysis under native and denaturing conditions (Figure 4), together with the gel filtration of the crude extracts and the purified proteins, indicated that the antibacterial proteins from both of these species form higher molecular aggregates or multimers in the fruiting body extracts. Furthermore, during the purification procedures these higher molecular protein complexes dissociated mostly into dimers in solution.

Analysis of the isoelectric points revealed that both of these proteins have similar isoelectric points, at approximately $\mathrm{pH}$ 6.5. The antibacterial protein from $A$. phalloides showed higher heterogeneity (Figure 4C). Several bands were observed for the A. phalloides protein with isoelectric focusing, which were probably the result of glycosylation variants, as N-glycosylation was confirmed for the antibacterial protein from A. phalloides (Figure 4D). On the other hand, N-glycosylation was not confirmed for the I. geotropa antibacterial protein (Figure 4D).

$\mathrm{N}$-terminal sequencing of both of these proteins did not provide conclusive data to enable primer design for gene sequence retrieval. Therefore, the individual spots from the I. geotropa 2D-PAGE separation (Supplementary Figure S1) were cut out, eluted and subjected to mass spectrometry analysis. However, only similarity to a bacterial dihydrolipoyl dehydrogenase (EC 1.8.1.4) with limited coverage was detected, which was not considered a significant hit. On the other hand, using mass spectrometry analysis the protein from $A$. phalloides with antibacterial activity was identified as toxophallin, an LAO that was isolated from A. phalloides fruiting bodies (Stasyk et al., 2010). Poor outcome of the N-terminal amino acid sequencing and mass spectrometry peptide fingerprinting is probably the consequence of the fact that genomes of these two fungal species are not yet available and the similarity to characterized LAOs from other organisms is too low to be detected.

L-amino acid oxidase activities were confirmed in the fractions with antibacterial activity after the gel filtration and hydrophobic interaction chromatography for both species. The proteins with antibacterial activities are therefore termed $A p \mathrm{LAO}$ and $C g \mathrm{LAO}$. The in-gel LAO activities (Figure 4A, lanes 5, 6) corresponded well to the bands of the non-denatured ApLAO (Figure 4A, lane 4) and $C g L A O$ (Figure 4A, lane 2), as observed under conditions of SDS-PAGE analysis.

\section{l. geotropa Produces LAO in Vegetative Mycelia}

A protein with antibacterial activity and LAO activity was also isolated from I. geotropa mycelia following the same procedures as for that from the fruiting bodies. Both the mycelium extract and the gel filtration fractions showed LAO activities that completely inhibited $R$. solanacearum growth
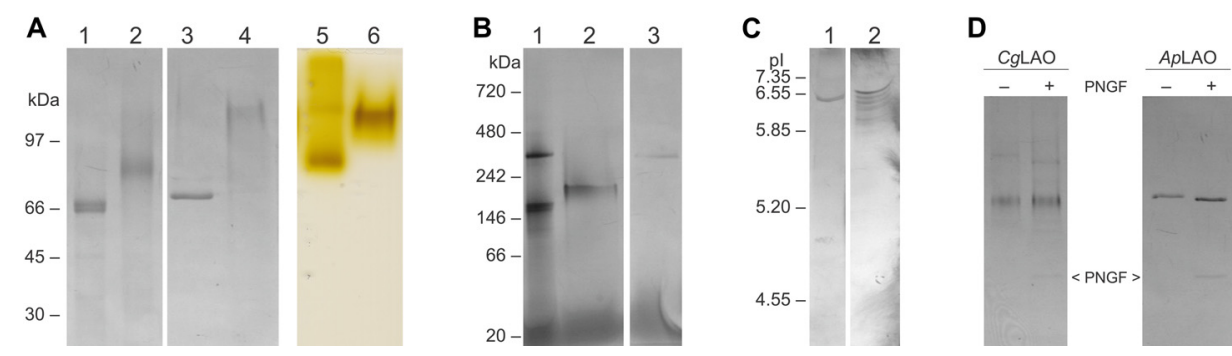

FIGURE 4 | Representative polyacrylamide electrophoretic analyses of purified proteins with antibacterial activity from I. geotropa and A. phalloides. (A) SDS-PAGE analysis in a 10\% polyacrylamide gel under denaturing and non-denaturing conditions showing Coomassie blue staining (lanes $1-4)$ and $\mathrm{H}_{2} \mathrm{O}_{2}$ production $(\mathrm{LAO}$ activity; lanes 5, 6). Lanes 1, 2, 5, CgLAO; lanes 3, 4, 6, ApLAO; lanes 1, 3, samples heated to $100^{\circ} \mathrm{C}$ for 10 min; lanes 2, 4, samples incubated at room temperature. Lanes 5, 6, LAO activities for CgLAO (lane 5) and ApLAO (lane 6). For $\mathrm{H}_{2} \mathrm{O}_{2}$ production, following SDS-PAGE under non-denaturing conditions in a $10 \%$ polyacrylamide gel, the $\mathrm{LAO}$ activity was revealed by staining for $\mathrm{H}_{2} \mathrm{O}_{2}$ production for $1 \mathrm{~h}$ using the $\mathrm{o}$-phenylenediamine-horseradish peroxidase system with $5 \mathrm{mM}$ L-Leu as substrate in $0.1 \mathrm{M}$ bis-Tris, pH 5.5. (B) Blue native PAGE analysis. Lane 1, purified CgLAO; lane 2, purified ApLAO; lane 3, purified CgmycLAO. (C) Isoelectric focusing analysis. Lane 1, purified CgLAO; lane 2, purified ApLAO. (D) SDS-PAGE analysis for deglycosylation using peptide-N-glycosidase F (PNGF) in a $10 \%$ silver-stained polyacrylamide gel. Left, purified CgLAO; right, purified ApLAO. 


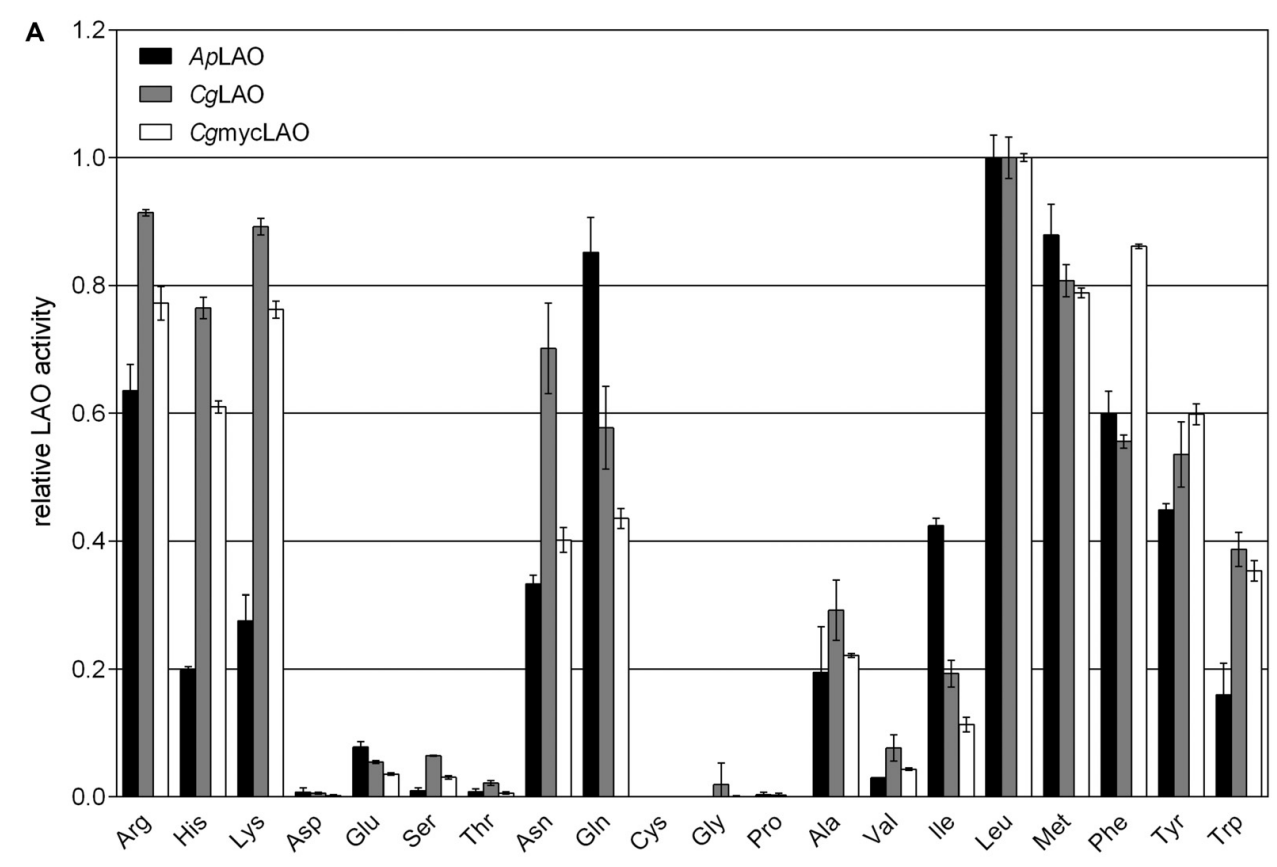

B

\begin{tabular}{lcccccc}
\hline & \multicolumn{2}{c}{ L-Leu } & \multicolumn{2}{c}{ L-Arg } & \multicolumn{2}{c}{ L-Gln } \\
& $K_{\mathrm{m}}[\mathrm{mM}]$ & $V_{\max }[\mu \mathrm{mol} / \mathrm{s}]$ & $K_{\mathrm{m}}[\mathrm{mM}]$ & $V_{\max }[\mu \mathrm{mol} / \mathrm{s}]$ & $K_{\mathrm{m}}[\mathrm{mM}]$ & $V_{\max }[\mu \mathrm{mol} / \mathrm{s}]$ \\
\hline ApLAO & $0.096 \pm 0.009$ & $1.98 \pm 0.05$ & $2.71 \pm 0.08$ & $1.82 \pm 0.06$ & $0.27 \pm 0.04$ & $2.31 \pm 0.05$ \\
CgLAO & $0.55 \pm 0.06$ & $1.13 \pm 0.03$ & $0.59 \pm 0.12$ & $1.22 \pm 0.09$ & $12.1 \pm 0.6$ & $1.53 \pm 0.04$ \\
CgmycLAO & $1.52 \pm 0.06$ & $0.34 \pm 0.04$ & $\mathrm{ND}$ & $\mathrm{ND}$ & $\mathrm{ND}$ & $\mathrm{ND}$ \\
\hline
\end{tabular}

FIGURE 5 | Substrate specificities and kinetic properties of ApLAO, CgLAO and CgmycLAO. (A) Quantitative analysis of different L-amino acid substrates (5 mM) at $\mathrm{pH} 7.5$ and $37^{\circ} \mathrm{C}$. Data are means \pm standard deviation normalized to L-Leu, the optimal substrate for both enzymes. (B) $\mathrm{K}_{\mathrm{m}}$ and $\mathrm{V}_{\max }$ were determined experimentally and using Michaelis-Menten equation.

(Supplementary Figure S2). Furthermore, concentrated spent medium from mycelium growth had no effect on $R$. solanacearum growth indicating that the antibacterial LAO is not secreted. The LAO isolated from the cultured vegetative mycelia of I. geotropa was termed CgmycLAO, and it showed very similar characteristics to that from I. geotropa fruiting bodies (CgLAO). CgmycLAO showed a single band of approximately $400 \mathrm{kDa}$ on native PAGE (Figure 4B), and one prominent band of approximately $65 \mathrm{kDa}$ on SDS-PAGE (Figure 3). Identification of CgmycLAO by mass spectrometry analysis was also not successful, as no similarity to identified peptides was found in the available databases.

\section{L-Amino Acid Oxidase Activity}

The ApLAO, CgLAO, and CgmycLAO showed similar broad substrate specificities for L-amino acids with hydrophobic and charged side chains (Figure 5A). They all showed their highest LAO activity against L-Leu, with $K_{\mathrm{m}}$ in the low millimolar range (Figure 5B). ApLAO showed approximately 2fold higher specific activity compared to CgLAO. Addition of the antioxidant agent ascorbic acid (at $0.1 \mathrm{mg} / \mathrm{mL}$ or higher) inhibited $A p \mathrm{LAO}, C g \mathrm{LAO}$, and CgmycLAO activities in vitro
(Supplementary Figure S3) similarly, as previously shown for toxophallin (Stasyk et al., 2010).

All three enzymes had a broad $\mathrm{pH}$ optimum (Figure 6), which peaked at $\mathrm{pH} 6$ for ApLAO and at $\mathrm{pH} 5$ for $C g \mathrm{LAO}$ and CgmycLAO. Furthermore, they had a wide $\mathrm{pH}$ range for their activities, with $>50 \%$ enzymatic activity in the $\mathrm{pH}$ range from $\mathrm{pH} 3$ to $\mathrm{pH} 10$.

\section{L-Leu LAO Activity Correlates With Antibacterial Activity in the Fractionated Extracts of Fungal Fruiting Bodies}

This study is a follow-up to the screening study of antibacterial activities against $R$. solanacearum in mushrooms (Erjavec et al., 2016), therefore, analysis of LAO mediated antibacterial activity was broadened in order to assess, whether it is widely distributed among fungal species or limited to a few species. The fruiting body extracts of 15 species of mushrooms covering one ascomycete and seven basidiomycete families were fractionated using gel filtration chromatography (Sephacryl S300). Their antibacterial activities against $R$. solanacearum and their LAO activities against L-Leu and the defined mixture of amino acids in CSM were determined for the fractions (Table 1 and 

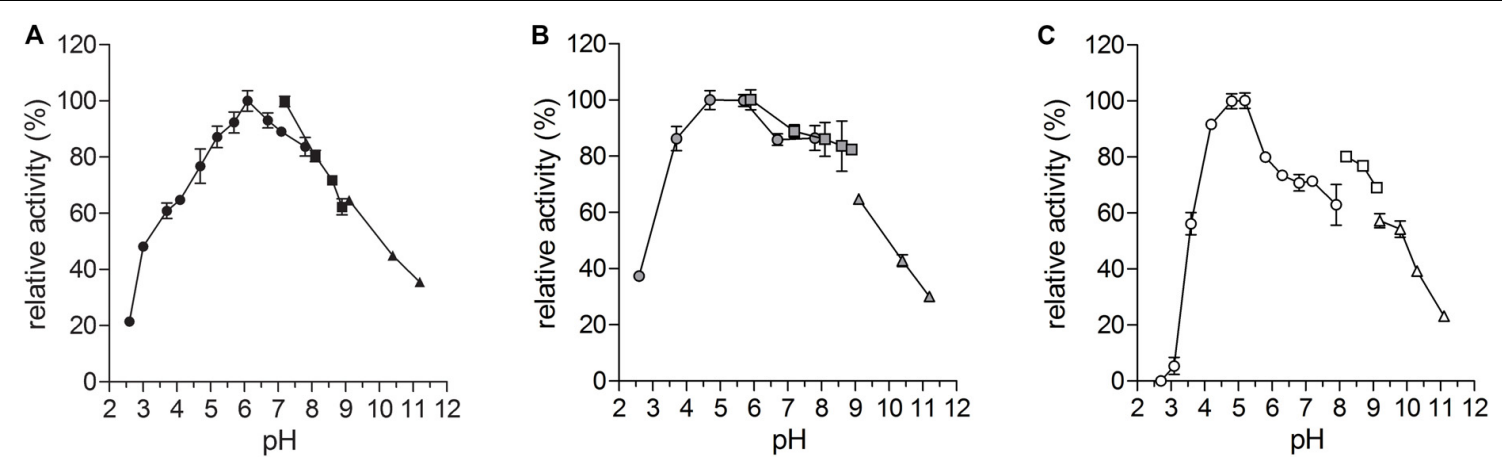

FIGURE 6 | pH optima of $A p\llcorner A O, C g\llcorner A O$ and CgmycLAO. pH range for activity of $A p L A O$ (A), CgLAO (B), and CgmycLAO (C) as analyzed using L-Leu as substrate: $\mathrm{pH} 2.6$ to $\mathrm{pH}$ 7.8, phosphate-citrate buffer (circles); $\mathrm{pH} 6$ to $\mathrm{pH}$ 9, K-phosphate buffer (squares); pH 9 to pH 11, carbonate-bicarbonate buffer (triangles). Data are means \pm standard deviation.

Supplementary Figure S4). The LAO activities against the CSM amino acids of the fractions detected using the in-gel activity method were also determined spectrophotometrically, with the exception of the Lepista nuda fractions, which only showed ingel LAO activities. The fractions of A. phalloides, I. geotropa, and Tuber mesentericum that showed LAO activity against the CSM amino acids were also active against L-Leu, and the same fractions also had antibacterial activities. On the other hand, the fractions of the Agaricus bisporus and Xerocomus badius extracts only showed LAO activities against the CSM amino acids, and they were not active against L-Leu and also did not have antibacterial activities. Similarly, the fractions of the Clitocybe nebularis extract that showed LAO activity only against the CSM amino acids were not active against L-Leu, and had no antibacterial activities. However, antibacterial activity was detected in one of the other fractions from the $C$. nebularis extract, which indicated the presence of a non-LAO antibacterial activity. Moreover, LAO activity was detected exclusively by the in-gel detection method using the CSM amino acids in one fraction of the L. nuda extract, which also showed antibacterial activity.

The LAO activities that were detected in-gel against the CSM amino acid substrate with apparent molecular masses of $50 \mathrm{kDa}$ and above correlated with the antibacterial activities. On the other hand, the fractions that showed LAO activities with apparent molecular masses of $30 \mathrm{kDa}$ or less did not have antibacterial activities.

A lack of antibacterial activity in vitro in the fruiting body extracts does not necessarily signify a lack of antibacterial compounds in these extracts. There were no antibacterial activities detected in the whole extracts from $L$. nuda and T. mesentericum, although there were antibacterial activities detected in their gel filtration fractions. Conversely, the T. saponaceum extract had antibacterial activity, but this was lost upon fractionation.

\section{LAO Activity Mediates the Antibacterial Effects on $E$. coli and $L$. lactis}

To determine the mode of action of these enzymes, the effects of $A p \mathrm{LAO}, \mathrm{CgLAO}$, and $C g$ mycLAO were examined on the growth of two model bacteria. Their antibacterial activities were greater against the Gram-negative E. coli than the Gram-positive L. lactis (Figures 7, 8). ApLAO, CgLAO, and CgmycLAO all slowed the growth rates of $E$. coli, and $C g L A O$ and $C g$ mycLAO also significantly prolonged the $E$. coli lag phase, which was up to 10 -fold longer. Also, ApLAO and CgLAO, but not CgmycLAO, promoted E. coli transition to the stationary phase at a lower optical density $\left(\mathrm{A}_{595}\right)$. On the other hand, the L. lactis growth rate and optical density at transition to the stationary phase was less affected by ApLAO, CgLAO and CgmycLAO, and the main effect of all three of these LAOs was for prolongation of the lag phase. The effect was less substantial than for E. coli, as the lag phase was at most tripled (by the highest concentration of CgLAO used).

Surprisingly, the catalase-negative L. lactis was more resistant to these LAO activities in terms of all of the growth parameters, as compared to E. coli, which expresses catalase. Nevertheless, the addition of catalase to the medium alleviated or abolished the effects of these LAO activities on both E. coli and L. lactis (Supplementary Figure S5). Furthermore, the addition of the preferred substrate of $A p \mathrm{LAO}, C g \mathrm{LAO}$, and $C g$ mycLAO to the minimal medium increased the antibacterial activity on $E$. coli of all three of these LAOs, and for all of the growth parameters (Supplementary Figure S6). These results confirm that the antibacterial effects of all three LAOs are indeed a consequence of the LAO activity by oxidative deamination of L-amino acids.

\section{LAO Activity Mediates the Antibacterial Effects on $R$. solanacearum}

The antibacterial activity of $A p \mathrm{LAO}, C g \mathrm{LAO}$, and $C g m y c L A O$ is due to their enzymatic activity. ApLAO and CgLAO showed similar antibacterial activities against $R$. solanacearum in YPG and $B G$ medium, with the minimum inhibitory concentration of $4.2 \mu \mathrm{g} / \mathrm{mL}$ in BG and $8.4 \mu \mathrm{g} / \mathrm{mL}$ in YPG for ApLAO and $25.8 \mu \mathrm{g} / \mathrm{mL}$ for $\mathrm{CgLAO}$ (Figure 9). The inhibitory activities of CgmycLAO were minimal, and were only detected at 20 -fold higher concentrations compared to CgLAO. The addition of catalase reduced the inhibitory effects of the LAO activity in a concentration-dependent manner, which confirmed that this 
A

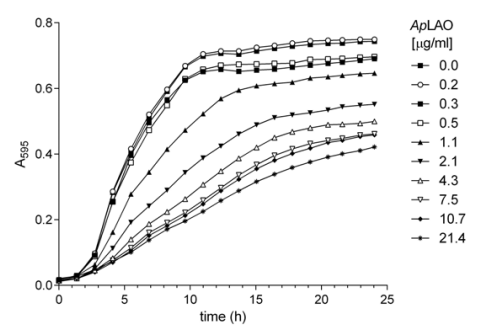

D

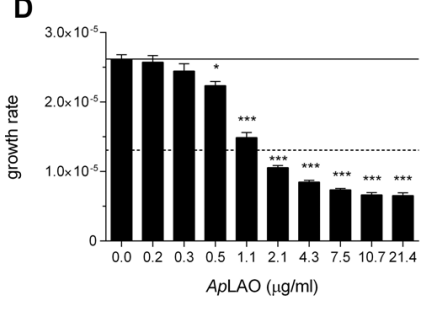

G

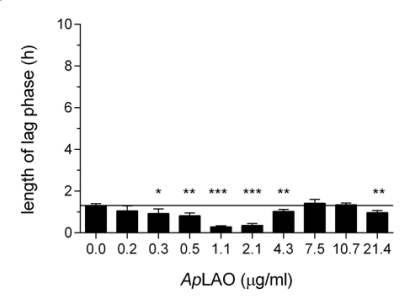

$\mathbf{J}$

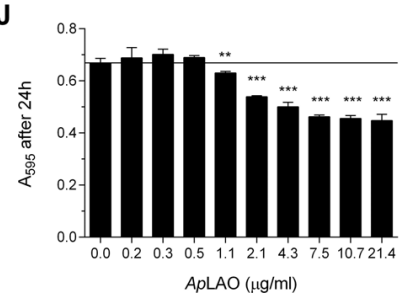

B

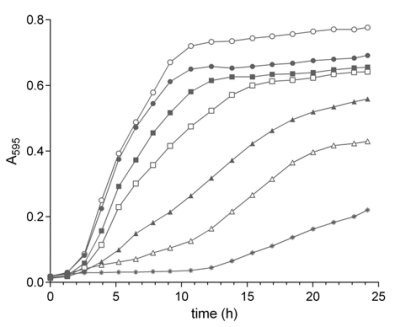

E

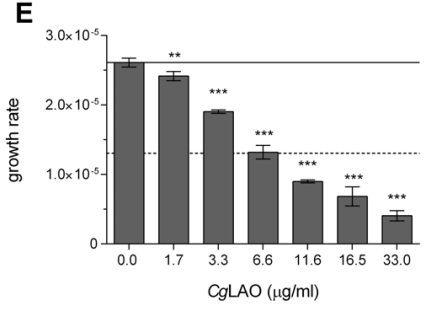

H

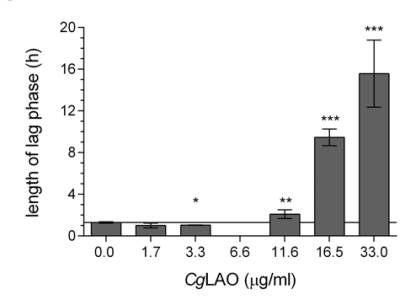

K

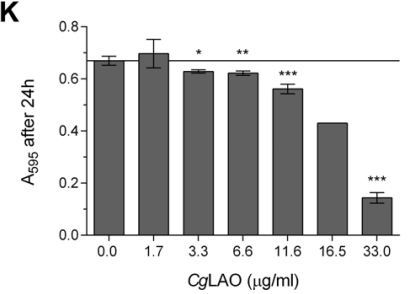

C

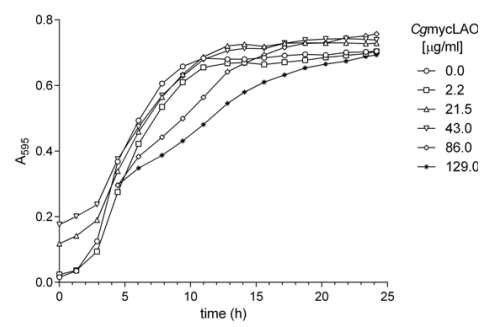

F

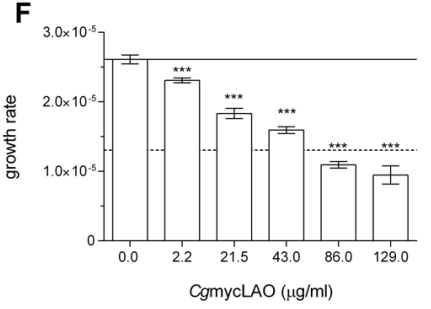

I

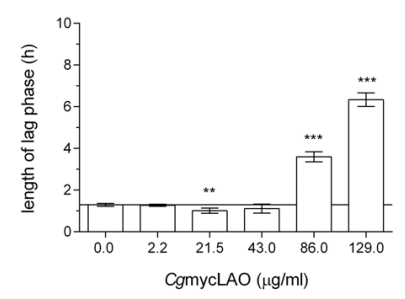

L

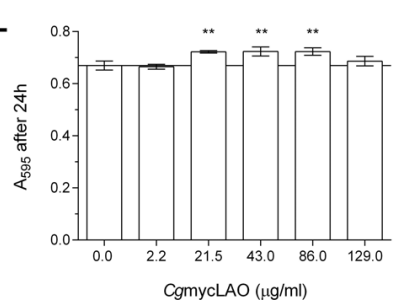

FIGURE 7 | Effects of ApLAO, CgLAO and CgmycLAO on E. coli growth measures. Representative E. coli growth curves (A-C) and derived growth parameters as growth rate (D-F), length of lag phase (G-I), and absorbance after $24 \mathrm{~h}(\mathbf{J}-\mathbf{L})$ in the absence and presence of increasing concentrations of $A p L A O(\mathbf{A}, \mathbf{D}, \mathbf{G}, \mathbf{J})$, CgLAO (B,E,H,K) and CgmycLAO (C,F,I,L). Data are means \pm standard deviation, with the analysis performed twice, each as three technical repeats. ${ }^{*} p<0.05$; ${ }^{* \star} p<0.01$; and ${ }^{* \star *} p<0.001$ (Student's $t$-tests vs. no addition control). Guiding lines help visualize the control value.

inhibitory activity is the consequence of the LAO enzymatic activity (Figure 9).

\section{Transmission Electron Microscopy of R. solanacearum}

Micrographs of $R$. solanacearum were produced by transmission electron microscopy, and these revealed the influences of $C g \mathrm{LAO}$ on the bacterial ultrastructure. The comparisons of the bacterial shapes before (Figure 10A) and after (Figures 10B,C) treatment with CgLAO indicated presence of "bulges" on the cell surface (Figures 10B,C, black arrows) and increased filamentous structure around the PHA granules (Figures 10B,C, white arrows). Control cells had a wrinkled outer membrane with a visible periplasmic space (Figure 10A), which was sometimes enlarged due to invagination of the inner membrane. After the CgLAO treatment, the volume of the periplasmic space appeared to increase mostly at the cell poles (Figures 10B,C, white arrowheads), although the plasma membrane was also seen to be detached from the cell wall in other places (Figure 10B, black arrowheads). The periplasmic space of the CgLAO-treated cells also appeared to contain more granulated material compared to the control cells, and the outer membrane became less wrinkled and looked smooth, and in some cases, amorphous (Figures 10B,C).

\section{In vivo Pathogenicity Tests}

For CgLAO and CgmycLAO, the inhibitory activities against $R$. solanacearum disease progression in vivo in tomato plants were confirmed, while ApLAO had no such activity in vivo. Tomato plants were used in the pathogenicity tests as these are an important $R$. solanacearum host plant, and they are also used as test plants in bacterial diagnostics. The A. phalloides 
A

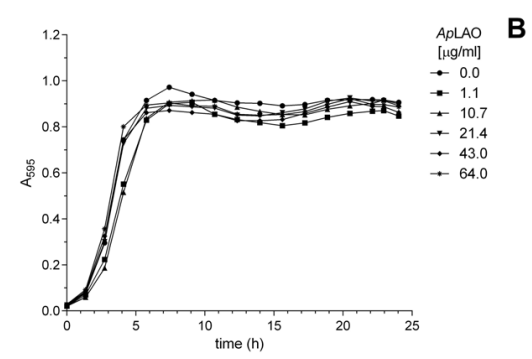

D

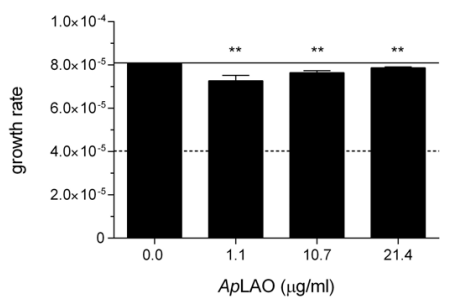

G

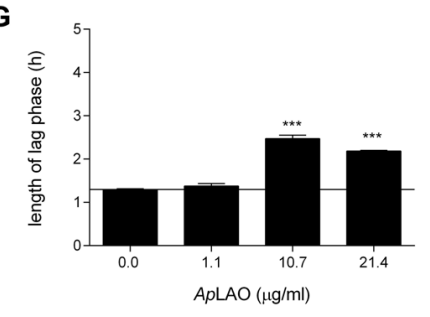

J

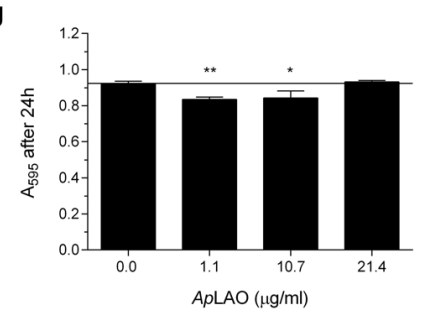

B

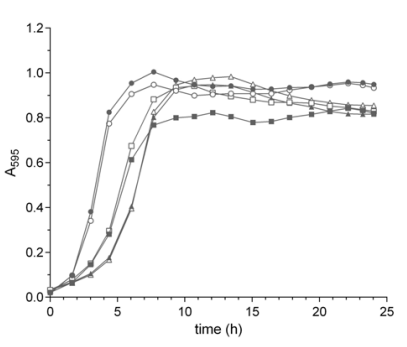

E

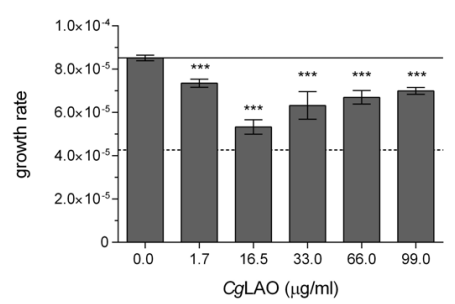

H

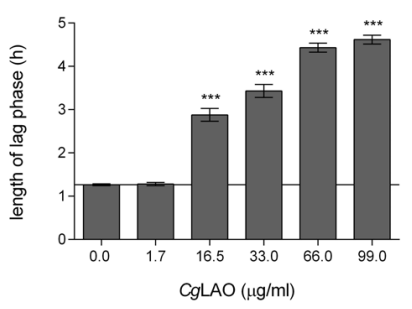

K

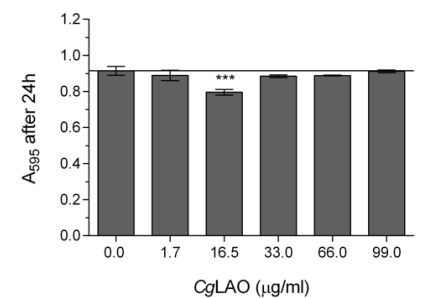

C

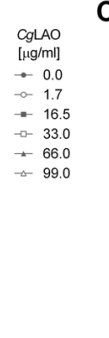

F

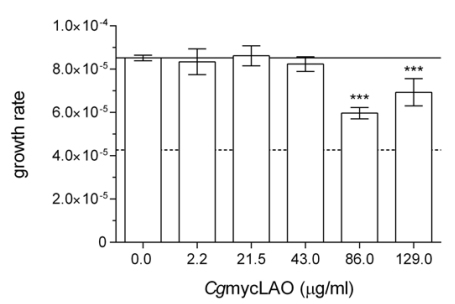

I

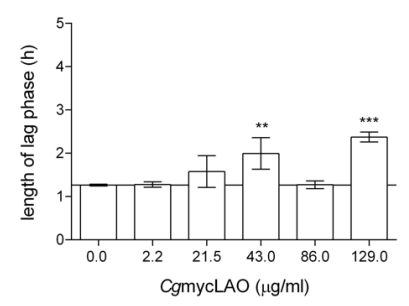

$\mathbf{L}$

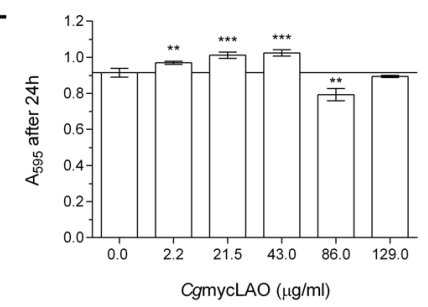

FIGURE 8 | Effects of ApLAO, CgLAO and CgmycLAO on L. lactis growth measures. Representative L. lactis growth curves (A-C) and derived growth parameters as growth rate (D-F), length of lag phase $(\mathbf{G}-\mathbf{I})$, and absorbance after $24 \mathrm{~h}(\mathbf{J}-\mathbf{L})$ in the absence and presence of increasing concentrations of $A$ pLAO (A,D,G,J), $\mathrm{Cg} L A O(\mathbf{B}, \mathbf{E}, \mathbf{H}, \mathbf{K})$ and CgmycLAO $\mathbf{( C , F , I , L )}$. Data are means \pm standard deviation, with the analysis performed twice, each as three technical repeats. ${ }^{\star} p<0.05$; ${ }^{\star \star} p<0.01 ;{ }^{\star \star \star} p<0.001$ (Student's $t$-tests vs. no addition control). Guiding lines help visualize the control value.

and I. geotropa extracts and their purified ApLAO, CgLAO, and CgmycLAO fractions were tested for in vivo activities, through comparison of their AUDPC values (Table 2). ApLAO had no effects on disease progression in the tomato plants, with AUDPC of 93, similar to previously observed effects (Erjavec et al., 2016). On the other hand, the I. geotropa extracts, CgLAO, the mycelium extract and CgmycLAO all significantly delayed disease progression in the tomato plants $(p<0.05$ or $<0.01$; Figure 11). This indicated that the protein in the extracts from the fruiting bodies and the mycelia of I. geotropa that had antibacterial activity was the purified $\mathrm{CgLAO}$ and $\mathrm{CgmycLAO}$. The same observations were made previously for a I. geotropa extract, with AUDPC of 75\% (Erjavec et al., 2016). The AUDPC for the CgmycLAO extract (75\%) was the same as that for the CgLAO fruiting body extract. The AUDPCs for $\mathrm{CgLAO}$ and $\mathrm{CgmycLAO}$ were higher compared to the extracts, at 79 and $85 \%$, respectively.

\section{LAOs Have Antibacterial Activities Against Several Plant Pathogenic Bacteria}

We assessed the scope of fungal LAOs antibacterial activities by analyzing their effect on the growth of different plant pathogenic bacteria. ApLAO $(33 \mu \mathrm{g} / \mathrm{mL})$ and $C g \mathrm{LAO}$ (103 $\mu \mathrm{g} / \mathrm{mL}$ ) showed inhibitory activities against several selected catalase-positive bacteria, with the exception of Erwinia amylovora (Table 3). Furthermore, ApLAO (100 $\mu \mathrm{g} / \mathrm{mL})$ completely inhibited growth measured at $24 \mathrm{~h}$ in YPG medium 

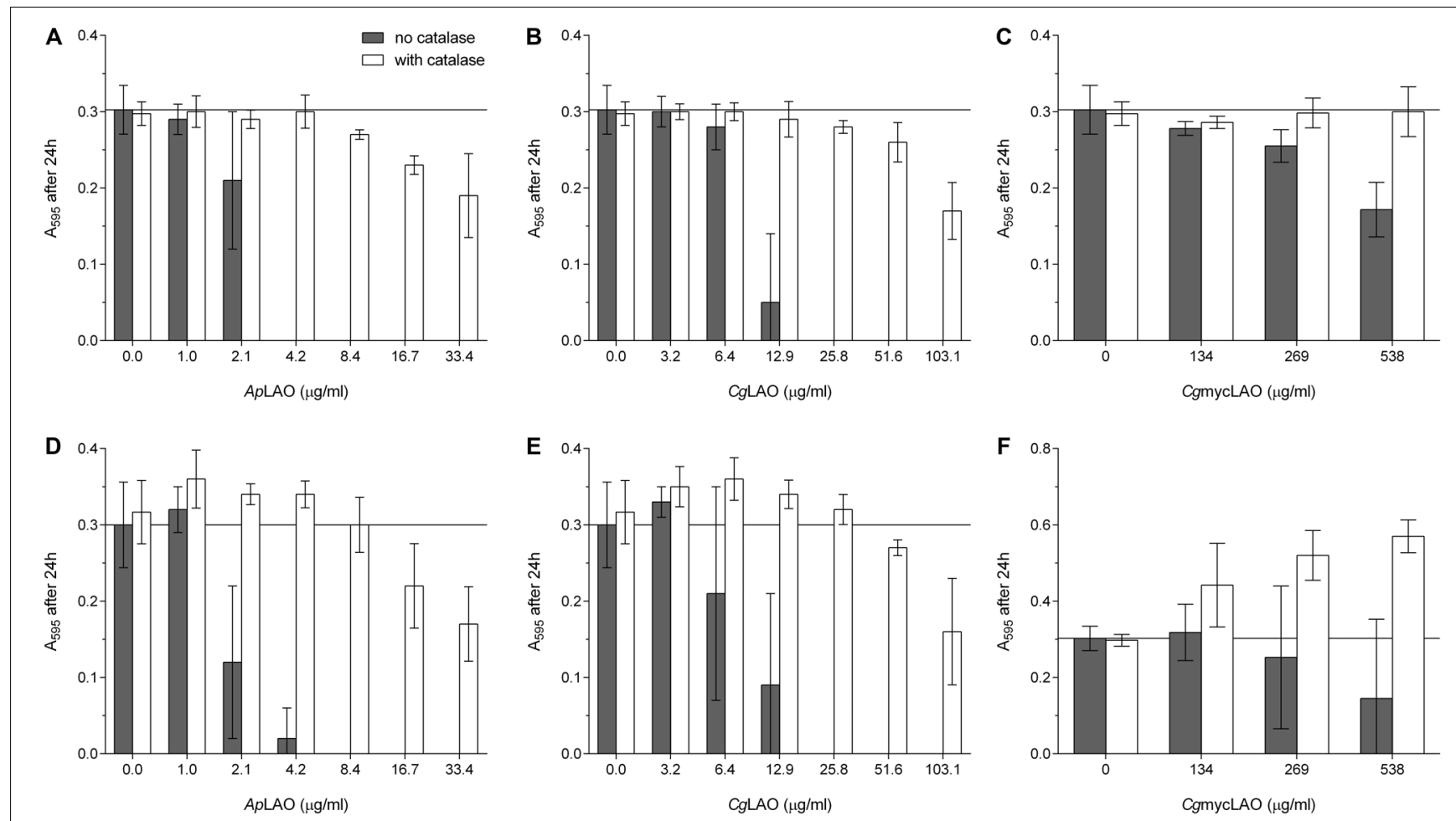

FIGURE 9 | Catalase removes the inhibition of $R$. solanacearum by ApLAO, CgLAO, and CgmycLAO. Representative absorbance after $24 \mathrm{~h}$ in the absence and presence of increasing concentrations of $A p L A O(\mathbf{A}, \mathbf{D}), C g L A O(B, E)$ and $C g m y c L A O(\mathbf{C}, \mathbf{F})$ without (closed columns) and with (open columns) addition of catalase. The analyses were carried out in BG medium (A-C) and YPG medium (D-F). Data are means \pm standard deviation, with the analysis performed twice, each as three technical repeats. Guiding lines help visualize the control value.
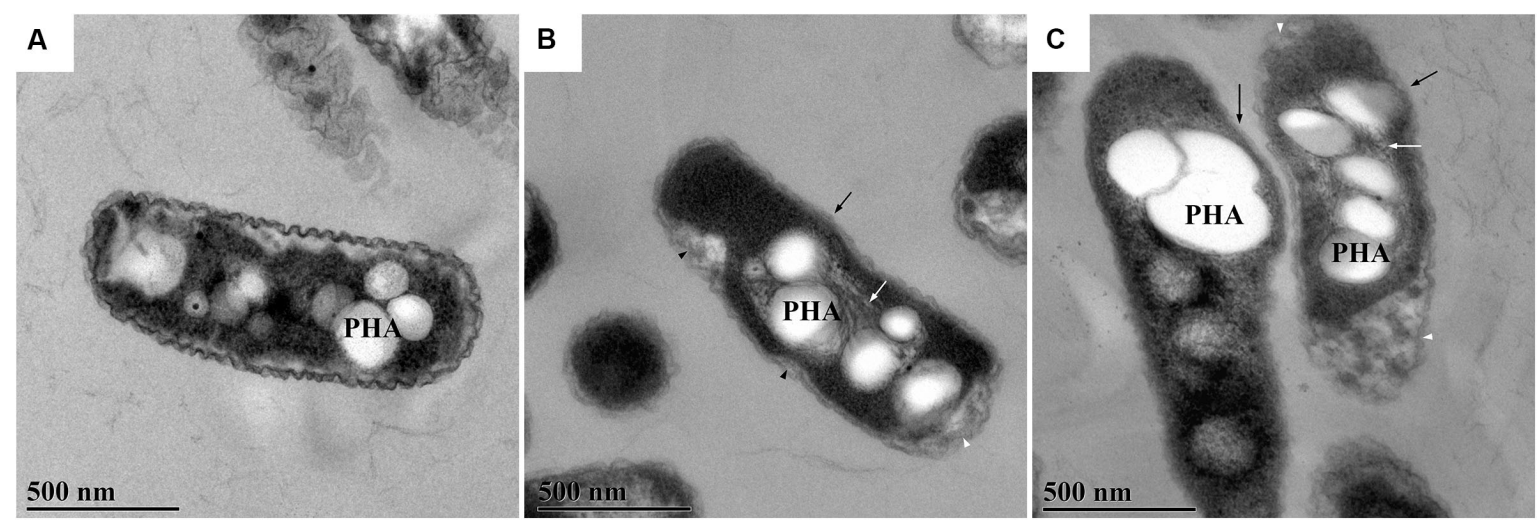

FIGURE 10 | Representative transmission electron microscopy after treatment of $R$. solanacearum with CgLAO. $R$. solanacearum were left untreated (A) or were treated (B,C) with CgLAO at $50 \mu \mathrm{g} / \mathrm{mL}$ for $2 \mathrm{~h}$. PHA, polyhydroxyalkanoate granules. (B,C) White arrows, filaments around granules; black arrows, bulge in the bacterial surface; black arrowheads, detachment of plasma membrane; white arrowheads, large periplasmic spaces at the poles of the cell.

of the following bacteria: A. tumefaciens (NCPPB 2437), Enterobacter sp. (NCCPB 4168), P. atrosepticum (NIB Z 620), P. carotovorum (NIB Z 623), D. chrysanthemi (NCPPB 402), E. coli (GSPB 48), R. mannitolilytica (CFBP 6737), and $X$. arboricola pv. pruni (NCPPB 416). CgmycLAO appeared to be less effective in vitro compared to ApLAO and $C g \mathrm{LAO}$, as the similar activities were seen at higher CgmycLAO concentrations.

\section{DISCUSSION}

Here, we have described the purification of antibacterial LAOs from two mushrooms: the poisonous death cap A. phalloides (ApLAO) and the edible trooping funnel I. geotropa (CgLAO). These were purified through two chromatographic steps following the initial activation and solubilization of the active LAO species using NaSCN and urea. More complex procedures 
TABLE 2 | In vitro antibacterial activities against $R$. solanacearum and in vivo (tomato cv. "Moneymaker") disease activities of the protein extracts and purified proteins.

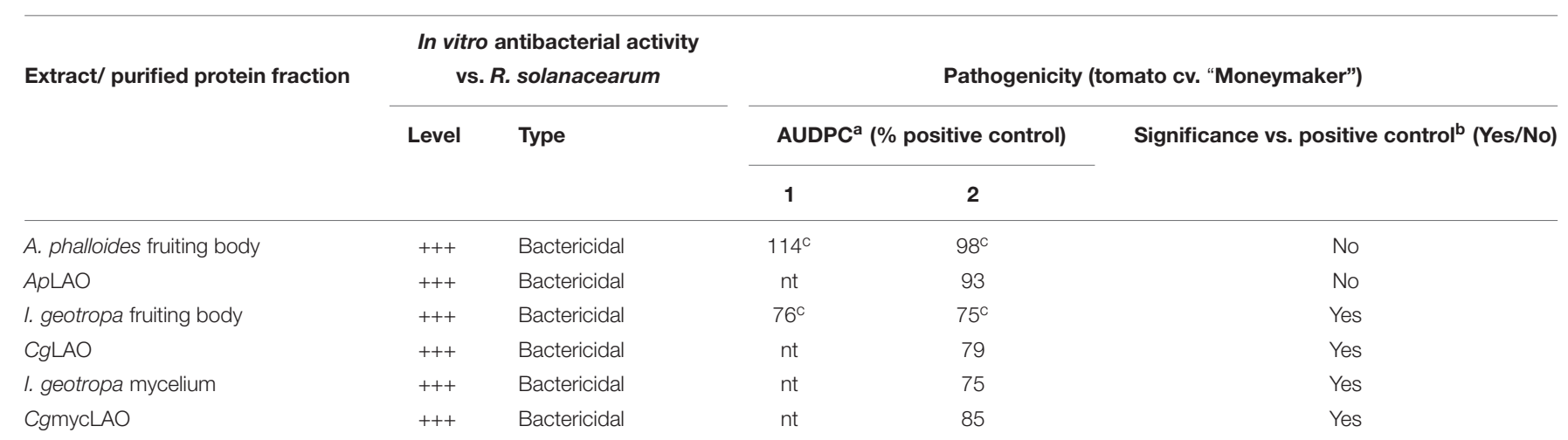

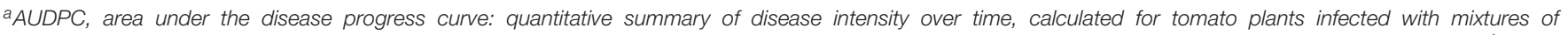

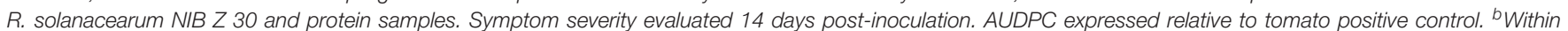

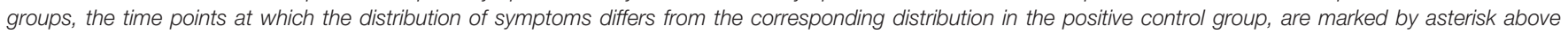

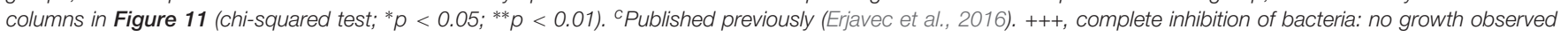
( $\leq 15 \%$ positive control $\left.A_{595}\right)$. nt, not tested.

TABLE 3 | Inhibitory activities of ApLAO, CgLAO and CgmycLAO against the selected bacteria.

\begin{tabular}{|c|c|c|c|c|c|}
\hline \multirow[t]{3}{*}{ Bacteria } & \multirow[t]{3}{*}{ Strain } & \multirow[t]{3}{*}{ Medium $^{a}$} & \multicolumn{3}{|c|}{ Growth after 24 h (\% positive control) } \\
\hline & & & ApLAO & CgLAO & CgmycLAO \\
\hline & & & $33 \mu \mathrm{g} / \mathrm{mL}$ & $103 \mu \mathrm{g} / \mathrm{mL}$ & $2.1 \mathrm{mg} / \mathrm{mL}$ \\
\hline Ralstonia solanacearum & NCPPB 4156 & CPG & 0 & 0 & 0 \\
\hline Dickeya sp. & NIB B16 & CPG & 77.7 & 0 & 0 \\
\hline Dickeya sp. & NIB S1 & CPG & 50.0 & 0 & 0 \\
\hline Dickeya fangzhongdai & DSMS 101947 & CPG & 278 & 0 & 0 \\
\hline Erwinia amylovora & NCPPB 683 & $\mathrm{~KB}$ & 100 & 69.7 & 90.9 \\
\hline Pseudomonas syringae pv. syringae & NCPPB 281 & $\mathrm{~KB}$ & 97.4 & 0 & 0 \\
\hline Clavibacter michiganensis subsp. michiganensis & NCPPB 2979 & NBYE & 0 & 0 & 0 \\
\hline
\end{tabular}

acomposition of media as described in Schaad et al. (2001).

have been used previously for the isolation of LAOs from fungal fruiting bodies and mycelia. Four- to six-step procedures comprising several steps of different types of chromatographies and protein precipitation were used for toxophallin and Trpoxidase purification (Furuya et al., 2000; Stasyk et al., 2008).

In our initial purification and identification of the antibacterial component in crude extracts of A. phalloides, I. geotropa, and I. geotropa mycelia, in all cases the antibacterial activities following gel filtration ran close to the void volume of the column. This indicated a relatively high molecular mass species of around 200 to $300 \mathrm{kDa}$. This would be attributable to relatively large protein assemblies, which can result from aggregation with other proteins or from multimerization of LAOs in the mushroom tissues and the crude extracts. Another observation was that there was significant precipitation of bioactive material during the concentrating of the crude extracts. When dissolved in $3 \mathrm{M}$ urea, these precipitates contained a significant amount of bioactive material. With the aim to help with the purification, the chaotropic agents NaSCN and urea were included in all of the crude extracts and gel filtration buffers with I. geotropa, as this provided an immediate several-fold increase in the measurable LAO activities in the I. geotropa extracts, and eventually in greater final yield of the corresponding LAO enzymes. This tendency to precipitate also remained during the next purification step of hydrophobic chromatography. A relatively low concentration of ammonium sulfate $(0.85 \mathrm{M})$ had to be used to achieve binding of the sample to the phenyl-Sepharose, the use of higher concentrations resulted in increased precipitation of protein that showed antibacterial and LAO activities.

The molecular masses of the purified ApLAO and CgLAO were estimated as 72 and $66 \mathrm{kDa}$, respectively, from the SDSPAGE analysis, and between 120 and $130 \mathrm{kDa}$ by gel filtration using native conditions, which suggested that these enzymes were dimeric in nature. This is consistent with the molecular masses of LAOs isolated from fruiting bodies and mycelia of other basidiomycetes. Monomers of L-Trp-oxidase from Coprinus sp. (Furuya et al., 2000) and an LAO from Hebeloma cylindrosporium (HcLAO) (Nuutinen et al., 2012) had molecular masses of 68 and $67 \mathrm{kDa}$, respectively, and assembled into hexamers $(420 \mathrm{kDa})$ and dimers $(140 \mathrm{kDa})$, respectively. Monomers of toxophallin (Stasyk et al., 2010) and toxovirin (Antonyuk et al., 2010) were identified as $55 \mathrm{kDa}$ proteins. The differences in the previously reported molecular mass of toxophallin compared to that in the present study can be attributed to the low accuracy of molecular mass estimations with SDS-PAGE. A range of molecular masses of LAO monomeric subunits have been reported from various 


\section{A Amanita phalloides fruiting body extract}

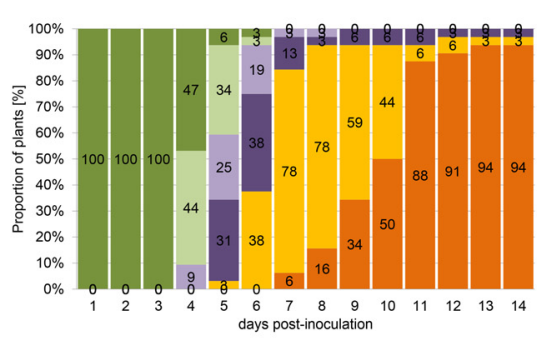

\section{B $\quad A p L A O$}

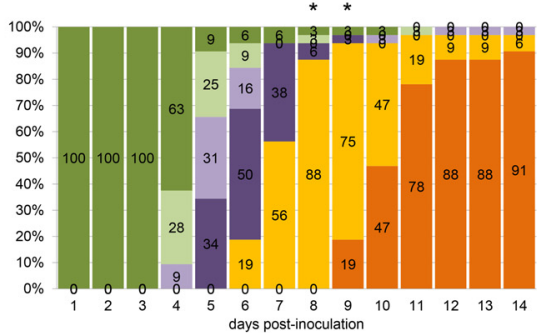

C Positive control

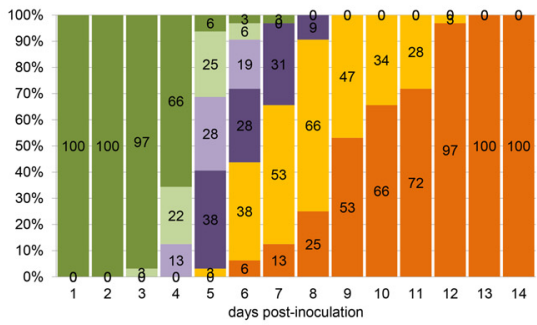

D Infundibulicybe geotropa fruiting body extract $\mathbf{E}$

CgLAO
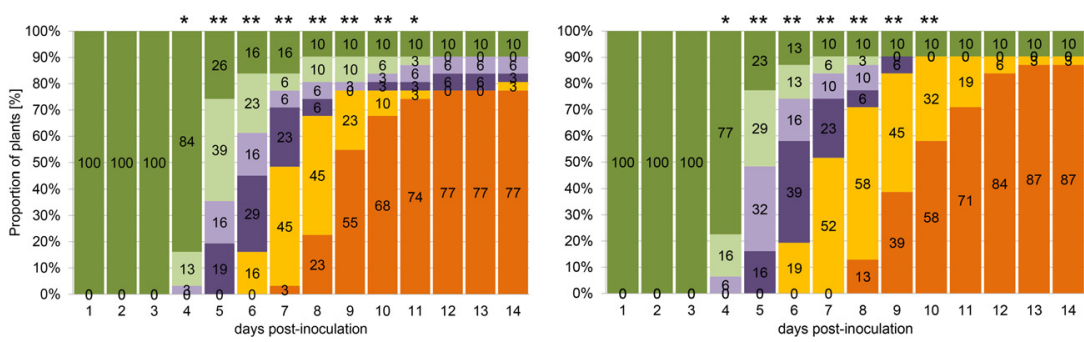

F Infundibulicybe geotropa mycelium extract

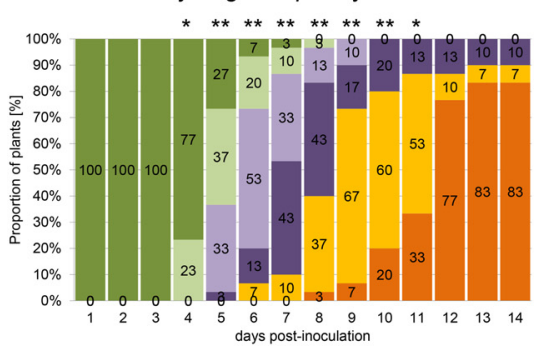

G CgmycLAO

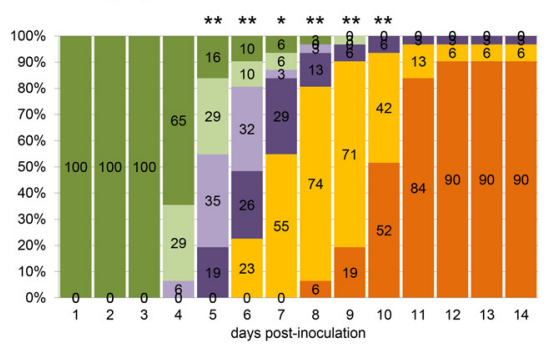

H Positive control

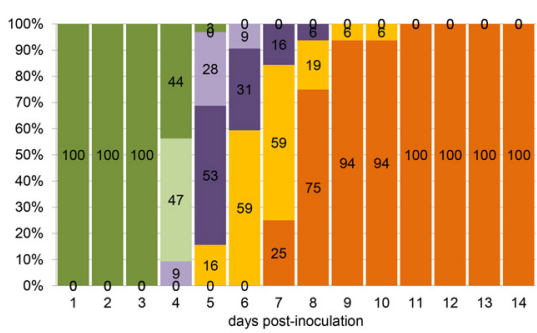

FIGURE 11 | Effects of extracts and purified LAOs on bacterial wilt disease progression in artificially inoculated potted tomato plants of cv. "Moneymaker." Plants were stem-inoculated with mixture of $R$. solanacearum $\left(10^{5} \mathrm{CFU} / \mathrm{mL}\right)$ and the extracts from the fruiting bodies of $A$. phalloides (A) and I. geotropa (D) and the mycelia of I. geotropa (F), or the purified $A p L A O(\mathbf{B}), C g L A O(\mathbf{E})$ or CgmycLAO (G), or with $R$. solanacearum alone $(\mathbf{C}, \mathbf{H}$; positive control). The experiments were performed in two growing chambers, one with plants for groups (A-C) and the other for groups (D-H). For each time point from 1 to 14 days, the symptoms are expressed as proportion of plants with symptoms for each grade according to Winstead and Kelman (1952): dark green, grade 0 (no symptoms); light green, grade 1 (one leaf wilted); light purple, grade 2 (2-3 leaves wilted); dark purple, grade 3 (all leaves except the tip of the plant wilted); yellow, grade 4 (all leaves and the tip of the plant wilted); orange, grade 5 (plant dead). Within groups, the times at which the distribution of the symptoms differed significantly from the corresponding distribution in the positive control group, are indicated: ${ }^{*} p<0.05$ and ${ }^{* *} p<0.01$ (chi-squared tests). The plants in the negative control groups did not show any symptoms.

microbial and animal sources, which have ranged from $43 \mathrm{kDa}$ for LAO from Streptococcus oligofermentas (Tong et al., 2008) to $85 \mathrm{kDa}$ for LAO from sea hare Aplysia kurodai (Kamiya et al., 1986). The molecular masses of the newly identified fungal LAOs are within the prevalent range of LAO molecular masses between 60 and $70 \mathrm{kDa}$. With the exception of the monomeric LAO escapin from sea hare Aplysia californica (Yang et al., 2005), these enzymes are mostly active as oligomers. They have included mainly dimers (Geueke and Hummel, 2002; Kitani et al., 2007; Yang et al., 2011; Guo et al., 2012), but also trimers (Kitani et al., 2010), and tetramers (Kamiya et al., 1986), with molecular masses ranging from 100 to $340 \mathrm{kDa}$. The initial isolation procedures that have generally been adapted to allow for such high molecular mass protein assemblies have indicated the presence of an array of possible aggregates or multimeric proteins in the fruiting bodies that show strong antibacterial activities. These have then generally been dissociated using chaotropic ions and urea during the purification procedures, which has resulted in predominantly LAO dimers present under the conditions described.

The isoelectric points of LAOs can be relatively variable. While most are acidic proteins with $\mathrm{pI}$ between $\mathrm{pH} 4$ and $\mathrm{pH}$ 5, a few have higher pIs, above pH 8 (Geueke and Hummel, 2002; Guo et al., 2012; Vargas et al., 2013). In contrast to the isoelectric points of ApLAO and $C g \mathrm{LAO}$ here as approximately at $\mathrm{pH}$ 6.5, slightly lower isoelectric points have been reported for toxophallin (pH 5.7) (Stasyk et al., 2008) and HcLAO (pH 5.4) (Nuutinen et al., 2012).

$\mathrm{N}$-glycosylation was shown here for ApLAO, while $C g \mathrm{LAO}$ did not appear to be $\mathrm{N}$-glycosylated. The glycosylation status of the LAOs from basidiomycetes has not been investigated, however, an indication of glycosylation of HcLAO was shown by 2D-PAGE analysis, which yielded several spots (Nuutinen et al., 2012). 
Animal and fungal LAOs with antibacterial activities have been shown to be glycoproteins (Yang et al., 2005, 2011; Kitani et al., 2007; Alves et al., 2008), although N-glycans appear not to be involved in the antibacterial activities, as deglycosylation did not reduce the antibacterial activity for a LAO from rockfish (Kitani et al., 2007), and a non-glycosylated bacterial LAO has shown antibacterial activity (Tong et al., 2008). Our results confirm that $\mathrm{N}$-glycans are not essential for antibacterial activity of LAOs as both non N-glycosylated CgLAO and N-glycosylated ApLAO showed strong antibacterial activity.

The slightly acidic $\mathrm{pH}$ optimum between $\mathrm{pH} 5$ and $\mathrm{pH} 6$ seen here for ApLAO and CgLAO differs from more basic $\mathrm{pH}$ optima reported for L-Trp oxidase, at pH 7 (Furuya et al., 2000), and for LAOs from Hebeloma spp. and Laccaria bicolor, at $\mathrm{pH}$ 8 (Nuutinen and Timonen, 2008; Nuutinen et al., 2012). LAO activities that show a broad $\mathrm{pH}$ range are, however, common to basidiomycete LAOs, thus being similar to, although not as expanded as, $A p \mathrm{LAO}$ and $C g \mathrm{LAO}$ here. $\mathrm{LAO}$ activities with broad $\mathrm{pH}$ ranges have been reported, such as from $\mathrm{pH} 6$ to $\mathrm{pH} 10$ for Hebeloma LAOs, and from $\mathrm{pH} 5$ to $\mathrm{pH} 11$ for Coprinus L-Trpoxidase (Furuya et al., 2000; Nuutinen and Timonen, 2008). Snake venom LAOs have their $\mathrm{pH}$ optimum between $\mathrm{pH} 7$ and 8.5 (Tan and Fung, 2008), and microbial LAOs show a broader $\mathrm{pH}$ optimum usually between pH 6 and pH 9 (Geueke and Hummel, 2002; Kurosawa et al., 2009; Yang et al., 2011; Pollegioni et al., 2013). Here described fungal LAOs showed extraordinarily wide $\mathrm{pH}$ optimum, which strengthens their potential for a wide array of applications.

L-amino acid oxidases have shown either broad or very narrow substrate specificities. The broad substrate specificities reported here for $A p \mathrm{LAO}$ and $C g \mathrm{LAO}$ were similarly reported for $\mathrm{HcLAO}$ and toxovirin (Antonyuk et al., 2010; Nuutinen et al., 2012), while L-Trp-oxidase from Coprinus has a narrow substrate specificity (Furuya et al., 2000). Converesely, snake venom LAOs generally have high specificities toward hydrophobic or aromatic amino acids, such as L-Phe, L-Leu, L-Met, and L-Ile (Lukasheva et al., 2011; Guo et al., 2012), and several marine animal LAOs have high specificities toward positively charged amino acids, such as L-Lys and L-Arg (Jimbo et al., 2003; Yang et al., 2005; Kitani et al., 2007, 2010). Broad substrate specificities for charged and aromatic amino acids have been shown for some bacterial (Geueke and Hummel, 2002; Tong et al., 2008) and fungal (Davis et al., 2005) LAOs, while others have shown very narrow specificities against one L-amino acid, and these have been named accordingly (Kusakabe et al., 1980; Arima et al., 2009; Pollegioni et al., 2013; Hossain et al., 2014).

Amanita phalloides and CgLAO are particularly stable enzymes that are resistant to repeated freezing and thawing cycles (our observations). In this regard, fungal LAOs are more similar to microbial enzymes that tend to be more robust and stable compared to those from animals. With a few exceptions, snake venom LAOs are thermo-labile enzymes that are inactivated by freezing but remain stable at $4^{\circ} \mathrm{C}$ (Tan and Fung, 2008; Guo et al., 2012; Pollegioni et al., 2013).

Amanita phalloides, CgLAO and CgmycLAO all showed broad specificities for their antibacterial actions, as they showed activities against both Gram-negative and Gram-positive bacteria, albeit that these were less pronounced for the Grampositive bacteria. Some degree of specificity was shown in the screening of their activities on the various plant pathogenic bacteria, where Dickeya spp. showed some resistance, and growth of Erwinia amylovora was not affected. This is consistent with other known LAOs, which in general have broad antibacterial activities that encompass both Gram-positive and Gram-negative bacteria, while their activities against fungi and yeast are generally lower (Yang et al., 2005; Guo et al., 2012).

The mechanism of the antibacterial activities here is attributed to the LAO enzymatic activity that leads to formation of the toxic $\mathrm{H}_{2} \mathrm{O}_{2}$. Therefore, their antimicrobial activities can be abolished by addition of catalase. The addition of catalase suppressed the antibacterial activities of $A p \mathrm{LAO}, C g \mathrm{LAO}$, and CgmycLAO against $R$. solanacearum, E. coli and L. lactis, which confirmed that these antibacterial activities are the consequence of $\mathrm{H}_{2} \mathrm{O}_{2}$ formation. Furthermore, significant contributions to these LAO activities comes from depletion of substrate L-amino acids and accumulation of other intermediates and their final products. For example, production of ammonia leads to a less acidic medium, and $\alpha$-keto acids can act as siderophores (Lukasheva et al., 2011; Hossain et al., 2014). In the present study, the addition of L-Leu to the minimal medium significantly enhanced the antibacterial activities of $A p \mathrm{LAO}, C g \mathrm{LAO}$, and CgmycLAO by providing more substrate for the LAO enzymatic activity and boost the production of $\mathrm{H}_{2} \mathrm{O}_{2}$.

The effects of LAO activities against the different parameters of the bacterial growth curves were more pronounced in terms of the extended lag phase on Gram-positive L. lactis, while all three monitored growth parameters were affected in E. coli. These were most probably caused by the oxidative stress mediated by $\mathrm{H}_{2} \mathrm{O}_{2}$ as similar effects comprising a prolonged lag phase and lower growth rates upon exposure to different $\mathrm{H}_{2} \mathrm{O}_{2}$ levels have been shown for different Aeromonas and Vibrio spp. (Wang et al., 2004), as well as for E. coli (Sahu and Behuria, 2018).

Binding of LAOs to the bacterial surface has been shown, which presumably enhances their antibacterial activities by the consequent increased local concentrations of $\mathrm{H}_{2} \mathrm{O}_{2}$ (Ehara et al., 2002; Lee et al., 2011). Despite several attempts, we have not been able to conclusively confirm the binding of $A p \mathrm{LAO}$ or $C g \mathrm{LAO}$ to the surface of $R$. solanacearum.

Another aspect of these LAO activities is the morphological changes that were detected for $R$. solanacearum after the addition of $C g \mathrm{LAO}$ here. These changes were mainly evident as the formation of bulges in the bacterial surface, and as a consequence, many bacteria became more curved than rod shaped. The S. schlegeli antibacterial protein and $\mathrm{H}_{2} \mathrm{O}_{2}$ have been shown to produce similar morphological changes to bacteria. However, these changes differ among the bacterial species, and can include bleb-like protrusions on the surface, cell elongation, and pore formation, which can be accompanied by the rough appearance of the cell surfaces (Kitani et al., 2008; Wang et al., 2011).

The morphological and ultrastructural changes in $R$. solanacearum were probably the consequences of the rearrangement of the PHA granules, which are believed to be involved in oxidative stress tolerance (Castro-Sowinski et al., 2010). This was also confirmed here by the increased 
fibrillated structure around the PHA granules. It has been shown that PHA synthesis enhances the tolerance of plant pathogenic Pseudomonas to oxidative stress (Fones and Preston, 2012). Reactive oxygen species, such as $\mathrm{H}_{2} \mathrm{O}_{2}$, can even stimulate PHA synthesis, as a protective function against stress. This is in part mediated by the protection of proteins from oxidative damage, with a protective efficiency greater than that of trehalose (Obruca et al., 2016; Al Rowaihi et al., 2018). The present study also indicated changes in the cell wall structure of $R$. solanacearum after the treatment with $C g L A O$. Instead of the cell wall being visibly divided into the inner and outer membranes, with the CgLAO treatment the majority of the cells had a less pronounced and structured cell wall. Interestingly, morphological changes to mammalian cells in culture have been reported after treatments with ApLAO, which showed a periplasmic localization (Pišlar et al., 2016).

The pathogenicity tests in the present study confirm that the I. geotropa LAO isolated from the fruiting bodies and mycelia can delay disease progression in tomato plants. To the best of our knowledge, this is the only study that has repeated in vivo testing and confirmed previously published results (Erjavec et al., 2016). Furthermore, in addition to the antibacterial activities defined for the extracts, these antibacterial activities were substantiated in vivo using the proteins purified from the extracts. The effect of the $C g \mathrm{LAO}$ fruiting body extract was stronger compared to the purified proteins $\mathrm{CgLAO}$ and CgmycLAO. This indicated that these enzymes might interact with other proteins, peptides or compounds in the extracts that enhanced their antibacterial activities but were lost during the purification. Interestingly, the antibacterial activities of ApLAO appeared to be greater in vitro, while the pathogenicity tests showed it as ineffective in vivo. Although $A p \mathrm{LAO}$ and CgLAO are both LAOs and they show similar biochemical characteristics, their LAO enzymatic activities do not appear to be sufficient to provide antibacterial protection to these plants in vivo. Potentially, the glycosylation state or interactions with other proteins confer this specificity and enhanced activity. The stronger activity of $\mathrm{CgLAO}$ in terms of the prolongation of the lag phase might have provided the plant with more time to mount an antibacterial response. On the other hand, the different in vivo activities of $A p \mathrm{LAO}$ and $C g \mathrm{LAO}$ might be the consequence of their interactions with the plant defense system. Importantly, the protective activity of $\mathrm{CgLAO}$ purified from the fruiting bodies was mirrored by CgmycLAO purified from the mycelia, as well by the simple aqueous extracts of the cultured mycelia, thus indicating their potential for their use as plant protection agents.

\section{CONCLUSION}

We identified new fungal LAOs with antibacterial activity and described the process of their purification from higher fungi as well as their comprehensive biochemical characterization. We showed their antibacterial activity in vitro against a broad range of Gram-negative and Gram-positive bacteria encompassing several species of phytopathogens. Moreover, in vivo antibacterial activity was demonstrated for LAOs from I. geotropa fruiting bodies and mycelia in tomato plants, while the strong antibacterial effect of ApLAO in vitro had no effect on disease progression in planta. This raises an important point to test the antibacterial effect of new candidate phytoprotective agents observed in vitro, also in vivo in the early steps of their development. We have also demonstrated that antibacterial and LAO activity is present and expressed in cultured mycelia of I. geotropa, which indicates that a constant source is available and strengthens their potential to be used as new biological phytoprotective agents. Similar antibacterial activity based on LAOs was observed in other fungal species showing fruiting bodies of higher fungi to be a valuable source of antimicrobials.

\section{DATA AVAILABILITY STATEMENT}

All datasets generated for this study are included in the article/Supplementary Material.

\section{AUTHOR CONTRIBUTIONS}

JB designed the study and purified proteins. JS designed and performed biochemical experiments and those using model microorganisms. JE and TD designed and performed experiments with $R$. solanacearum. MT performed and analyzed TEM. MR and JK provided the resources. JB and JS wrote the manuscript. JE, MT, MR, and JK reviewed and edited the manuscript.

\section{FUNDING}

This study was supported by the Slovenian Research Agency (Grants Nos. P4-0127 to JK and P4-0165 to MR). The funders had no role in study design, data collection and analysis, decision to publish, or preparation of the manuscript.

\section{ACKNOWLEDGMENTS}

The authors are grateful to Adrijana Leonardi for help with the 2D-PAGE and protein N-terminal sequence analysis, to Jure Pohleven for help with the mass spectrometry analysis, to Lidija Matičic for help with the in vitro testing of antibacterial activity, and to Chris Berrie for critical reading and language editing of the manuscript.

\section{SUPPLEMENTARY MATERIAL}

The Supplementary Material for this article can be found online at: https://www.frontiersin.org/articles/10.3389/fmicb.2020. 00977/full\#supplementary-material 


\section{REFERENCES}

Al Rowaihi, I. S., Paillier, A., Rasul, S., Karan, R., Grotzinger, S. W., Takanabe, K., et al. (2018). Poly(3-hydroxybutyrate) production in an integrated electromicrobial setup: Investigation under stress-inducing conditions. PLoS One 13:e0196079. doi: 10.1371/journal.pone.0196079

Allen, C., Prior, P., and Hayward, A. C. (2005). Bacterial wilt Disease and the Ralstonia Solanacearum Species Complex. St. Paul, MN: American Phytopathological Society.

Alves, R. M., Antonucci, G. A., Paiva, H. H., Cintra, A. C., Franco, J. J., MendoncaFranqueiro, E. P., et al. (2008). Evidence of caspase-mediated apoptosis induced by l-amino acid oxidase isolated from Bothrops atrox snake venom. Comp. Biochem. Physiol. Pt. A Mol. Integr. Physiol. 151, 542-550. doi: 10.1016/j.cbpa. 2008.07.007

Anith, K. N., Momol, M. T., Kloepper, J. W., Marois, J. J., Olson, S. M., and Jones, J. B. (2004). Efficacy of plant growth-promoting rhizobacteria, acibenzolar-Smethyl, and soil amendment for integrated management of bacterial wilt on tomato. Plant Dis. 88, 669-673. doi: 10.1094/PDIS.2004.88.6.669

Antonyuk, V. O., Klyuchivska, O. Y., and Stoika, R. S. (2010). Cytotoxic proteins of Amanita virosa Secr. mushroom: purification, characteristics and action towards mammalian cells. Toxicon 55, 1297-1305. doi: 10.1016/j.toxicon.2010. 01.023

Arima, J., Sasaki, C., Sakaguchi, C., Mizuno, H., Tamura, T., Kashima, A., et al. (2009). Structural characterization of L-glutamate oxidase from Streptomyces sp. X-119-6. FEBS J. 276, 3894-3903. doi: 10.1111/j.1742-4658.2009.07103.x

Baranyi, J., and Roberts, T. A. (1994). A dynamic approach to predicting bacterial growth in food. Int. J. Food Microbiol. 23, 277-294. doi: 10.1016/0168-1605(94) 90157-0

Castro-Sowinski, S., Burdman, S., Matan, O., and Okon, Y. (2010). "Natural Functions of Bacterial Polyhydroxyalkanoates," in Plastics from Bacteria: Natural Functions and Applications, ed. G.-Q. Chen (Berlin: Springer-Verlag).

Davis, M. A., Askin, M. C., and Hynes, M. J. (2005). Amino acid catabolism by an areA-regulated gene encoding an L-amino acid oxidase with broad substrate specificity in Aspergillus nidulans. Appl. Environ. Microbiol. 71, 3551-3555. doi: 10.1128/AEM.71.7.3551-3555.2005

De mendiburu, F. (2020). Statistical Procedures for Agricultural Research using R. Package Agricolae. (Online publication). Available online at: https://tarwi. lamolina.edu.pe/ fmendiburu (accessed January 19, 2020).

Du, X. Y., and Clemetson, K. J. (2002). Snake venom L-amino acid oxidases. Toxicon 40, 659-665.

Ehara, T., Kitajima, S., Kanzawa, N., Tamiya, T., and Tsuchiya, T. (2002). Antimicrobial action of achacin is mediated by L-amino acid oxidase activity. FEBS Lett. 531, 509-512. doi: 10.1016/s0014-5793(02)03608-6

Erjavec, J., Ravnikar, M., Brzin, J., Grebenc, T., Blejec, A., Želko Gosak, M., et al. (2016). Antibacterial activity of wild mushroom extracts on bacterial wilt pathogen, Ralstonia solanacearum. Plant Dis. 100, 453-464. doi: 10.1094/PDIS08-14-0812-RE

Fernandez-Patron, C., Castellanos-Serra, L., and Rodriguez, P. (1992). Reverse staining of sodium dodecyl sulfate polyacrylamide gels by imidazole-zinc salts: sensitive detection of unmodified proteins. Bio. Tech. 12, 564-573.

Fones, H., and Preston, G. M. (2012). Reactive oxygen and oxidative stress tolerance in plant pathogenic Pseudomonas. FEMS Microbiol. Lett. 327, 1-8. doi: 10.1111/j.1574-6968.2011.02449.x

Furuya, Y., Sawada, H., Hirahara, T., Ito, K., Ohshiro, T., and Izumi, Y. (2000). A novel enzyme, L-tryptophan oxidase, from a basidiomycete, Coprinus sp. SF-1: purification and characterization. Biosci. Biotechnol. Biochem. 64, 1486-1493. doi: 10.1271/bbb.64.1486

Ganten, D., Ruckpaul, K., Birchmeier, W., Epplen, J. T., Genser, K., Gossen, M. (eds), et al. (2006). "Peptide mass fingerprinting," in Encyclopedic Reference of Genomics and Proteomics in Molecular Medicine, (Berlin: Springer Berlin Heidelberg), 1377-1377.

Geueke, B., and Hummel, W. (2002). A new bacterial L-amino acid oxidase with a broad substrate specificity: purification and characterization. Enzyme Microb. Technol. 31, 77-87.

Guo, C., Liu, S., Yao, Y., Zhang, Q., and Sun, M. Z. (2012). Past decade study of snake venom L-amino acid oxidase. Toxicon 60, 302-311. doi: 10.1016/j. toxicon.2012.05.001
Hong, J. C., Momol, M. T., Ji, P. S., Olson, S. M., Colee, J., and Jones, J. B. (2011). Management of bacterial wilt in tomatoes with thymol and acibenzolarS-methyl. Crop. Protect. 30, 1340-1345.

Hossain, G. S., Li, J., Shin, H. D., Du, G., Liu, L., and Chen, J. (2014). L-Amino acid oxidases from microbial sources: types, properties, functions, and applications. Appl. Microbiol. Biotechnol. 98, 1507-1515. doi: 10.1007/s00253-013-5444-2

Izidoro, L. F., Sobrinho, J. C., Mendes, M. M., Costa, T. R., Grabner, A. N., Rodrigues, V. M., et al. (2014). Snake venom L-amino acid oxidases: trends in pharmacology and biochemistry. BioMed Res. Int. 2014, 196754. doi: 10.1155/ 2014/196754

Ji, P., Momol, M. T., Olson, S. M., Pradhanang, P. M., and Jones, J. B. (2005). Evaluation of thymol as biofumigant for control of bacterial wilt of tomato under field conditions. Plant Dis. 89, 497-500. doi: 10.1094/PD-89-0497

Jimbo, M., Nakanishi, F., Sakai, R., Muramoto, K., and Kamiya, H. (2003). Characterization of L-amino acid oxidase and antimicrobial activity of aplysianin A, a sea hare-derived antitumor-antimicrobial protein. Fish. Sci. 69, 1240-1246.

Kamiya, H., Muramoto, K., and Yamazaki, M. (1986). Aplysianin-A, an antibacterial and antineoplastic glycoprotein in the albumen gland of a sea hare. Aplysia kurodai. Experientia 42, 1065-1067. doi: 10.1007/bf01940736

Kishimoto, M., and Takahashi, T. (2001). A spectrophotometric microplate assay for L-amino acid oxidase. Analy. Biochem. 298, 136-139. doi: 10.1006/abio. 2001.5381

Kitani, Y., Ishida, M., Ishizaki, S., and Nagashima, Y. (2010). Discovery of serum L-amino acid oxidase in the rockfish Sebastes schlegeli: isolation and biochemical characterization. Comp. Biochem. Physiol. B Biochem. Mol. Biol. 157, 351-356. doi: 10.1016/j.cbpb.2010.08.006

Kitani, Y., Kikuchi, N., Zhang, G., Ishizaki, S., Shimakura, K., Shiomi, K., et al. (2008). Antibacterial action of L-amino acid oxidase from the skin mucus of rockfish Sebastes schlegelii. Comp. Biochem. Physiol. Pt. B Biochem. Mol. Biol. 149, 394-400. doi: 10.1016/j.cbpb.2007.10.013

Kitani, Y., Tsukamoto, C., Zhang, G., Nagai, H., Ishida, M., Ishizaki, S., et al. (2007). Identification of an antibacterial protein as L-amino acid oxidase in the skin mucus of rockfish Sebastes schlegeli. FEBS J. 274, 125-136. doi: 10.1111/j.17424658.2006.05570.x

Kurosawa, N., Hirata, T., and Suzuki, H. (2009). Characterization of putative tryptophan monooxygenase from Ralstonia solanacearum. J. Biochem. 146, 23-32. doi: 10.1093/jb/mvp040

Kusakabe, H., Kodama, K., Kuninaka, A., Yoshino, H., Misono, H., and Soda, K. (1980). A new antitumor enzyme, L-lysine alpha-oxidase from Trichoderma viride. Purification and enzymological properties. J. Biol. Chem. 255, 976-981.

Lee, M. L., Tan, N. H., Fung, S. Y., and Sekaran, S. D. (2011). Antibacterial action of a heat-stable form of L-amino acid oxidase isolated from king cobra (Ophiophagus hannah) venom. Compar. Biochem. Physiol. Toxicol. Pharmacol. 153, 237-242. doi: 10.1016/j.cbpc.2010.11.001

Lukasheva, E. V., Efremova, A. A., Treshalina, E. M. Y., Medentzev, A. G., and Berezov, T. T. (2011). L-Amino oxidases: properties and molecular mechanisms of action. Biochemistry (Moscow) 5, 337-345. doi: 10.18097/pbmc20125804372

Madden, L. V., Hughes, G., and Van Den Bosch, F. (2007). The Study of Plant Disease Epidemics. St. Paul, MN: APS Press.

Magnelli, P., Bielik, A., and Guthrie, E. (2012). "Identification and characterization of protein glycosylation using specific endo- and exoglycosidases," in Protein Expression in Mammalian Cells. Methods in Molecular Biology (Methods and Protocols), Vol. 801, ed. J. Hartley (New Jersey: Humana Press).

Maji, S., and Chakrabartty, P. K. (2014). Biocontrol of bacterial wilt of tomato caused by Ralstonia solanacearum by isolates of plant growth promoting rhizobacteria. Austr. J. Crop Sci. 8, 208-214. doi: 10.1007/s11274-011-0975-0

Messiha, N. A. S., Van Bruggen, A. H. C., Van Diepeningen, A. D., De Vos, O. J., Termorshuizen, A. J., Tjou-Tam-Sin, N. N. A., et al. (2007). Potato brown rot incidence and severity under different management and amendment regimes in different soil types. Eur. J. Plant Pathol. 119, 367-381.

Nuutinen, J. T., Marttinen, E., Soliymani, R., Hilden, K., and Timonen, S. (2012). LAmino acid oxidase of the fungus Hebeloma cylindrosporum displays substrate preference towards glutamate. Microbiology 158, 272-283. doi: 10.1099/mic.0. 054486-0

Nuutinen, J. T., and Timonen, S. (2008). Identification of nitrogen mineralization enzymes, L-amino acid oxidases, from the ectomycorrhizal fungi Hebeloma spp. 
and Laccaria bicolor. Mycol. Res. 112, 1453-1464. doi: 10.1016/j.mycres.2008. 06.023

Obruca, S., Sedlacek, P., Mravec, F., Samek, O., and Marova, I. (2016). Evaluation of 3-hydroxybutyrate as an enzyme-protective agent against heating and oxidative damage and its potential role in stress response of poly(3-hydroxybutyrate) accumulating cells. Appl. Microbiol. Biotechnol. 100, 1365-1376. doi: 10.1007/ s00253-015-7162-4

Payne, D. J., Gwynn, M. N., Holmes, D. J., and Pompliano, D. L. (2007). Drugs for bad bugs: confronting the challenges of antibacterial discovery. Nat. Rev. Drug Discover. 6, 29-40. doi: 10.1038/nrd2201

Pišlar, A., Sabotič, J., Šlenc, J., Brzin, J., and Kos, J. (2016). Cytotoxic L-amino-acid oxidases from Amanita phalloides and Clitocybe geotropa induce caspasedependent apoptosis. Cell Death Discover. 2:16021. doi: 10.1038/cddiscovery. 2016.21

Pohleven, J., Brzin, J., Vrabec, L., Leonardi, A., Cokl, A., Strukelj, B., et al. (2011). Basidiomycete Clitocybe nebularis is rich in lectins with insecticidal activities. Appl. Microbiol. Biotechnol. 91, 1141-1148. doi: 10.1007/s00253-0113236-0

Pollegioni, L., Motta, P., and Molla, G. (2013). L-amino acid oxidase as biocatalyst: a dream too far? Appl. Microbiol. Biotechnol. 97, 9323-9341. doi: 10.1007/ s00253-013-5230- 1

R Development Core Team (2008). A Language and Environment for Statistical Computing. Online publication. Vienna: R Development Core Team.

Reim, D. F., and Speicher, D. W. (2001). N-terminal sequence analysis of proteins and peptides. Curr. Protoc. Protein Sci. Chapter 11, Unit 11.10. doi: 10.1002/ 0471140864.ps1110s57

Sabotič, J., Ohm, R. A., and Kunzler, M. (2016). Entomotoxic and nematotoxic lectins and protease inhibitors from fungal fruiting bodies. Appl. Microbiol. Biotechnol. 100, 91-111. doi: 10.1007/s00253-015-7075-2

Sahu, P. K., Gupta, A., Kumari, K. P., Kedarnath, Lavanya, G., and Yadav, A. K. (2017). "Attempts for biological control of Ralstonia solanacearum by using beneficial microorganisms," in Agriculturally Important Microbes for Sustainable Agriculture, eds V. S. Meena, P. K. Mishra, J. K. Bisht, and A. Pattanayak (Singapore: Springer Nature Singapore Pte Ltd).

Sahu, S. K., and Behuria, H. G. (2018). Biochemical characterization of $\mathrm{H}_{2} \mathrm{O}_{2}$ induced oxidative stress in E.coli. J. Appl. Microbiol. Biochem. 2:10. doi: 10. 1371/journal.pone.0106942

Schaad, N. W., Jones, J. B., and Chun, W. (2001). Laboratory Guide for Identification of Plant Pathogenic Bacteria. St. Paul, MN: American Phytopathological Society.

Šmid, I., Gruden, K., Buh Gašparič, M., Koruza, K., Petek, M., Pohleven, J., et al. (2013). Inhibition of the growth of Colorado potato beetle larvae by macrocypins, protease inhibitors from the parasol mushroom. J. Agricult. Food Chem. 61, 12499-12509. doi: 10.1021/jf403615f

Šmid, I., Rotter, A., Gruden, K., Brzin, J., Buh Gašparič, M., Kos, J., et al. (2015). Clitocypin, a fungal cysteine protease inhibitor, exerts its insecticidal effect on Colorado potato beetle larvae by inhibiting their digestive cysteine proteases. Pesticide Biochem. Physiol. 122, 59-66. doi: 10.1016/j.pestbp.2014. 12.022

Stasyk, T., Lootsik, M., Hellman, U., Wernstedt, C., Souchelnytskyi, S., and Stoika, R. (2008). A new protein from death cap Amanita phalloides: isolation and study of cytotoxic activity. Stud. Biol. 2, 21-32.

Stasyk, T., Lutsik-Kordovsky, M., Wernstedt, C., Antonyuk, V., Klyuchivska, O., Souchelnytskyi, S., et al. (2010). A new highly toxic protein isolated from the death cap Amanita phalloides is an L-amino acid oxidase. FEBS J. 277, 1260-1269. doi: 10.1111/j.1742-4658.2010.07557.x
Takakura, Y., Oka, N., Suzuki, J., Tsukamoto, H., and Ishida, Y. (2012). Intercellular production of Tamavidin 1, a biotin-binding protein from tamogitake mushroom, confers resistance to the blast fungus Magnaporthe oryzae in transgenic rice. Mol. Biotechnol. 51, 9-17. doi: 10.1007/s12033-011-9435-1

Tan, N.-H., and Fung, S.-Y. (2008). Snake venom L-amino acid oxidases and their potential biomedical applications. Malays. J. Biochem. Mol. Biol. 16, 1-10.

Tong, H., Chen, W., Shi, W., Qi, F., and Dong, X. (2008). SO-LAAO, a novel L-amino acid oxidase that enables Streptococcus oligofermentans to outcompete Streptococcus mutans by generating $\mathrm{H}_{2} \mathrm{O}_{2}$ from peptone. J. Bacteriol. 190, 4716-4721. doi: 10.1128/JB.00363-08

Vargas, L. J., Quintana, J. C., Pereanez, J. A., Nunez, V., Sanz, L., and Calvete, J. (2013). Cloning and characterization of an antibacterial L-amino acid oxidase from Crotalus durissus cumanensis venom. Toxicon 64, 1-11. doi: 10.1016/j. toxicon.2012.11.027

Wang, F., Li, R., Xie, M., and Li, A. (2011). The serum of rabbitfish (Siganus oramin) has antimicrobial activity to some pathogenic organisms and a novel serum L-amino acid oxidase is isolated. Fish Shellf. Immunol. 30, 1095-1108. doi: 10.1016/j.fsi.2011.02.004

Wang, Y., Leung, P. C., Qian, P., and Gu, J. D. (2004). Effects of UV, $\mathrm{H}_{2} \mathrm{O}_{2}$ and $\mathrm{Fe}^{3+}$ on the growth of four environmental isolates of Aeromonas and Vibrio species from a mangrove environment. Microb. Environ. 19, 163-171.

Winstead, N. N., and Kelman, A. (1952). Inoculation techniques for evaluating resistance to Pseudomonas solanacearum. Phytopathology 42, 628-634. doi: 10.1186/s13007-019-0530-9

Wullings, B. A., Van Beuningen, A. R., Janse, J. D., and Akkermans, A. D. L. (1998). Detection of Ralstonia solanacearum, which causes brown rot of potato, by fluorescent in situ hybridization with $23 \mathrm{~S}$ rRNA-targeted probes. Appl. Environ. Microbiol. 64, 4546-4554.

Yang, C. A., Cheng, C. H., Lo, C. T., Liu, S. Y., Lee, J. W., and Peng, K. C. (2011). A novel L-amino acid oxidase from Trichoderma harzianum ETS 323 associated with antagonism of Rhizoctonia solani. J. Agricult. Food Chem. 59, 4519-4526. doi: $10.1021 /$ jf104603w

Yang, H. C., Johnson, P. M., Ko, K. C., Kamio, M., Germann, M. W., Derby, C. D., et al. (2005). Cloning, characterization and expression of escapin, a broadly antimicrobial FAD-containing L-amino acid oxidase from ink of the sea hare Aplysia californica. J. Exp. Biol. 208, 3609-3622. doi: 10.1242/jeb.01795

Yuliar, Nion, Y. A., and Toyota, K. (2015). Recent trends in control methods for bacterial wilt diseases caused by Ralstonia solanacearum. Microbes Environ. 30, 1-11. doi: 10.1264/jsme2.ME14144

Zheng, S., Liu, Q., Zhang, G., Wang, H., and Ng, T. B. (2010). Purification and characterization of an antibacterial protein from dried fruiting bodies of the wild mushroom Clitocybe sinopica. Acta Biochim. Polon. 57, 43-48.

Žun, G., Kos, J., and Sabotič, J. (2017). Higher fungi are a rich source of L-amino acid oxidases. 3 Biotech 7:230. doi: 10.1007/s13205-017-0813-7

Conflict of Interest: The authors declare that the research was conducted in the absence of any commercial or financial relationships that could be construed as a potential conflict of interest.

Copyright (c) 2020 Sabotič, Brzin, Erjavec, Dreo, Tušek Žnidarič, Ravnikar and Kos. This is an open-access article distributed under the terms of the Creative Commons Attribution License (CC BY). The use, distribution or reproduction in other forums is permitted, provided the original author(s) and the copyright owner(s) are credited and that the original publication in this journal is cited, in accordance with accepted academic practice. No use, distribution or reproduction is permitted which does not comply with these terms. 